\section{Kữ Kamonu Eğitim Dergisi Kastamonu Education Journal}

Kasım 2019 Cilt:27 Sayı:6

kefdergi.kastamonu.edu.tr
Başvuru Tarihi/Received: 16.04.2019

Kabul Tarihi/Accepted: 24.06.2019

DOI: $10.24106 /$ kefdergi.3736

\title{
İlköğretim Matematik Öğretmeni Adaylarının Sahip Oldukları Matematik Tarihi Bilgileri ile ilgili Değişen Algıları: Pedagojik Deneyimlerin Rolü
}

\section{The Changing Perceptions of Prospective Middle School Mathematics Teachers on Their own Knowledge of History of Mathematics: The Role of Pedagogical Experiences}

\section{Öz}

\author{
Fadime ULUSOY ${ }^{1}$ Dilek GIRIT-YILDIZ ${ }^{2}$
}

Bu araştırma, ilköğretim matematik öğretmen adaylarının pedagojik deneyimler içeren Matematik Tarihi dersi öncesinde ve sonrasında matematik tarihi bilmenin gerekliliği konusunda ve kendi sahip oldukları matematik tarihi bilgileriyle ilgili algılarının neler olduğunu ve bu algılarda nasıl değişimler yaşandığını keşfetmeyi amaçlamıştır. Araştırma, ilköğretim matematik öğretmenliği programının son sınıfında öğrenim gören 32 öğretmen adayı ile gerçekleştirilmiştir. Çalışmada veriler, ders öncesi ve ders sonrası açık uçlu sorulara verilen yazılı cevaplar, öğretmen adaylarının hazırladıkları ders planları, araştırmacı notları ve derslerde yapılan sınıf tartışmaları aracılığıyla elde edilmiştir. Araştırma sonuçları, öğretmen adaylarının bir matematik öğretmenin (i) genel kültür ve saygınlık kazanmak, (ii) konu alan bilgilerini güçlendirmek, (iii) öğretim sürecini güçlendirmek ve (iv) öğrencileri matematiğe karşı duyuşsal olarak desteklemek için matematik tarihi bilmeleri gerektiği düşüncelerine sahip olduklarını göstermiştir. Pedagojik deneyimler içeren Matematik Tarihi dersi sonrasında bu düşüncelerdeki eğilimlerde ders öncesine göre belli değişimlerin olduğu görülmüştür. Diğer taraftan, araştırma sonuçları öğretmen adaylarının ders öncesinde kendi matematik tarihi bilgilerini çoğunlukla yüzeysel ve orta derece olarak tanıladıklarını göstermiştir. Ders sonrasında kendi bilgileriyle ilgili algılarında dört temel değişim ortaya çıkmıştır: (i) yüzeyselden-orta dereceye; (ii) orta dereceden-orta dereceye; (iii) orta dereceden-derine ve (iv) derinden-orta dereceye olarak gruplandırımıştır. Elde edilen sonuçlar, öğretmen adaylarının Matematik Tarihi ile ilgili pedagojik deneyimler (ör. ders kitaplarında matematik tarihinin analizi, matematik tarihi içerikli ders planı tasarlama) yaşadıkça matematik tarihini sadece bir genel kültür bileşeni olarak görmek yerine derslerinde nasıl kullanabilecekleriyle ilgilendiklerini göstermiştir. Bu nedenle, öğretmen adayları hangi matematik konusunda matematik tarihinin nasıl kullanılacağının ciddi bir bilgi birikimi ve tecrübe gerektirdiğini fark etmiş ve ders öncesinde matematik tarihi bilgileriyle ilgili sahip oldukları algıları kritik ederek değiştirmişlerdir.

Anahtar Kelimeler: matematik tarihi, öğretmen adayları, pedagojik deneyimler, algılar

\begin{abstract}
This study aims to explore what the perceptions of prospective middle school mathematics teachers about their own knowledge of history of mathematics before and after History of Mathematics course with pedagogical experiences and how their perceptions change through these experiences. The research was carried out with 32 prospective teachers in the last year of the teacher education program. In the study, the data were collected through responses to open-ended questions written before- and after-course, lesson plans prepared by prospective teachers, researchers' notes and classroom discussions. The results showed that prospective teachers think that a mathematics teacher should know history of mathematics to (i) gain general culture and respect, (ii) strengthen their content knowledge, (iii) strengthen the teaching process, and (iv) support students' affective dispositions towards mathematics. After the History of Mathematics course with pedagogical experiences, there were certain changes in the tendencies in these thoughts compared to the thoughts provided before the course. On the other hand, the results of this study showed that the prospective teachers identified their knowledge of history of mathematics mostly as superficial and moderate levels before the course. After the course, four common changes were found in the perceptions about their knowledge of history of mathematics. They were grouped as follows: (i) from superficial to moderate; (ii) from moderate to moderate; (iii) from moderate to deep and (iv) from deep to moderate. The results showed that prospective teachers were interested in how they could use mathematics in their lessons instead of just seeing history of mathematics like a general culture component as they had pedagogical experiences related to the history of mathematics (e.g. analysis of history of mathematics in textbooks, history of mathematics integrated lesson plan designs). Therefore, since prospective teachers realized that history of mathematics requires serious knowledge and experiences, they changed their perceptions about their knowledge of history of mathematics by criticizing their initial perceptions.
\end{abstract}

Keywords: history of mathematics, prospective teachers, pedagogical experiences, perceptions

1. Kastamonu Üniversitesi, Eğitim Fakültesi, Matematik ve Fen Eğitimi Bölümü, Kastamonu, Türkiye, https://orcid.org/0000-0003-3393-8778

2. Trakya Üniversitesi, Eğitim Fakültesi, Matematik ve Fen Eğitimi Bölümü, Edirne, Türkiye; https://orcid.org/0000-0003-3406-075X

Atıf / Citation: Ulusoy, F. ve Girit-Yıldız, D. (2019). İlköğretim matematik öğretmeni adaylarının sahip oldukları matematik tarihi bilgileri ile ilgili değişen algıları: Pedagojik deneyimlerin rolü. Kastamonu Education Journal, 27(6), 2729-2746. doi:10.24106/kefdergi.3736 


\section{Extended Abstract}

Introduction: The mathematical concepts have their origins from history (Bagni, 2008). Educators have recognized the value of the history of mathematics in teaching and learning at the beginning of the twentieth century (Barwell, 1913; Furinghetti \& Radford, 2002). They suggest to use history for teaching mathematics. According to educators, there are several reasons to be interested in history of mathematics such as to humanize mathematics, to understand the development of mathematics through history and to highlight obstacles in mathematical understanding (Ellington, 1998; Fauvel, 1991; Fried, 2001). Some recent studies emphasize the importance of investigating the use of history of mathematics in the scope of affective aspects such as prospective teachers' beliefs and perceptions about history of mathematics (e. g. Alpaslan, 2011; Panasuk \& Horton, 2012). Teacher education programs are suitable places to explain the potential use of history of mathematics in learning and teaching before prospective teachers are actively involved in their professions (Freudenthal, 1981). However, teacher training programs are criticized in terms of providing pedagogical opportunities in the history of mathematics in both national (Alpaslan \& Haser, 2012) and international studies (Fauvel, 1991; Furinghetti, 1997). In this study, a history of mathematics course that includes pedagogical experiences was prepared. In this course, prospective teachers learn hows and whys of using history of mathematics in teaching of mathematical concepts in middle grade levels. Thus, this study aims to explore what the perceptions of prospective middle school mathematics teachers about their own knowledge of history of mathematics before and after History of Mathematics Course with Pedagogical Experiences (e.g. analysis of history of mathematics in textbooks and history of mathematics integrated lesson plan designs) and how their perceptions change as they experienced pedagogical opportunities to use history in learning and teaching of mathematics.

Method: 2 middle school mathematics prospective teachers in the last year of the teacher education program participated to this exploratory study in a public university in Turkey. The content of History of Mathematics (HoM) courses in the program does not establish a relationship between history and pedagogy of mathematics in Turkey (Alpaslan \& Haser, 2012). For this reason, in the current study, the researchers decided to change the structure of the course by combining history and pedagogy of HoM in the design of course. In this sense, the use of history in mathematics was explained both as a tool and as a goal (Jankvist, 2009) in the course. Furthermore, illumination-, module- and history-based approaches (Jankvist, 2009) were exemplified and discussed during the course. Additionally, prospective teachers examined middle school mathematics textbooks in terms of presentations and using of history of mathematics with their groups. In the following of the course, they also prepared worksheets to integrate history of mathematics to the lessons of mathematics. In order to collect data, we asked prospective teachers to write a pre-reflection paper that is related to what they think about whether a mathematics teacher should know history of mathematics and if yes/ no why?. Importantly, it was also asked them to write the details of what they perceive their knowledge of history of mathematics. We collected both reflections papers for the same questions before and after the course. We examined data sources according to content analysis. We produced codes and themes based on the data.

Results: The results of the study revealed that prospective teachers think that mathematics teachers should know history of mathematics in order to (i) gain general culture and respect, (ii) strengthen their content knowledge, (iii) strengthen the teaching process, and (iv) to support their students' affective dispositions towards mathematics. Before HoM-course, they mostly see HoM as a tool to strengthen teaching mathematical concepts. Furthermore, they mentioned HoM as a cultural knowledge component before the course. However, they tended to see HoM as a tool to support students' affective dispositions towards mathematics learning. On the other hand, the results of this study indicated that the prospective teachers identified their knowledge of history of mathematics mostly superficial and moderate levels before the course. Their knowledge was limited to the name, formula of famous mathematicians and the historical/mathematical developments in some specific civilizations. However, after the course, their perceptions about their own knowledge of HoM were changed significantly. We categorized these changes into four groups such as (i) from superficial to moderate, (ii) from moderate to moderate, (iii) from moderate to deep and (iv) from deep to moderate. Although prospective teachers thought that they increased their knowledge of HoM, most of them did not find their knowledge sufficient to integrate HoM to learning environments. Thus, as prospective teachers experienced pedagogical opportunities related to the use of history of mathematics in teaching processes they were interested in how they could use mathematics in their lessons instead of just seeing history of mathematics like a general cultural component. Therefore, prospective teachers realized that history of mathematics requires serious knowledge and experiences and they changed their perceptions about their knowledge of history of mathematics by criticizing their initial perceptions. 


\section{Giriş}

Matematiksel kavramların kökenleri, kavramların tarihsel olarak gelişimi ile yakından ilişkilidir (Bagni, 2008). Eğitimciler, yirminci yüzyılın başlarında matematik tarihinin matematik öğrenme ve öğretme açısından taşıdığı önemi fark ederek bu konular üzerine yoğunlaşmaya başlamışlardır (Barwell, 1913; Furinghetti ve Radford, 2002). Araştırmacılara göre öğrenme ve öğretme süreçlerinde matematik tarihine yer vermek için önemli birçok neden bulunmaktadır. Örneğin matematik tarihi, matematiğin insanlığın çabaları sonucunda oluştuğunu görmeye, tarih boyunca matematikle ilgili yaşanan gelişimleri/değişimleri yorumlamaya ve kavramların öğrenilmesinde karşılaşılan engelleri anlamaya yardımcı olur (Ellington, 1998; Fauvel, 1991; Fried, 2001, Furinghetti ve Karp, 2018; Radford, 2000). Bazı eğitimciler, matematik tarihinin öğrenme açısından sağladığı bilişsel faydalara ek olarak öğrencilerin araştırma yapma becerilerini ve duyuşsal gelişimlerini (ör. Özgüven kazanma, olumlu inanış geliştirme) desteklediği sonucuna da varmıştı (Fried, 2001; Savizi, 2007). Diğer taraftan, öğrencilerin matematiksel kavramlarla ilgili zorlukları ve yanlış anlamaları, matematik tarihindeki epistemolojik engellerle benzerlik göstermektedir. Bu konuda, Furinghetti (2004) tarihin matematiğe entegre edilmesinin öğrencilerin matematik algılarına olumlu anlamda katkılar sunabileceğini belirtmektedir. Bu yönleriyle, matematik eğitiminde tarih, öğretmenler tarafindan kendi matematik bilgilerini geliştirme ve ele aldıkları matematiksel içerikler için alternatif pedagojik firsatlar sağlama amaçlarıyla kullanılmaktadır (Furinghetti, 2004).

Son yıllarda uluslararası çalışmalara ek olarak (Clark 2012; Philippou ve Christou, 1998), ülkemizde matematik tarihi ile ilgili konular çeşitli biçimlerde ele alınmaktadır. Bu konuda, (i) matematik tarihinin ders kitaplarında sunuluş biçimleri (Baki ve Bütüner, 2013; Erdoğan, Eşmen ve Fındık, 2015; Mersin ve Durmuş, 2018; Tan-Şişman ve Kirez, 2018), (ii) eğitim-öğretim faaliyetlerinde farkıı kullanımları (Baki ve Güven, 2009; Bütüner, 2011; Ersoy ve Öksüz, 2016; Karakuş, 2009; Özdemir ve Yıldız, 2015) ve (iii) derslerde matematik tarihi kullanıma yönelik öğretmen görüşleri (Hatisaru, Erbaş ve Çetinkaya, 2011; Sözen, 2013; Yıldız ve Baki, 2016) ile ilgili çalışmalar sayıca artmaktadır. Ülkemizde matematik tarihine 2005 yıından sonra ders kitaplarında yer verilmeye başlanmıştır. Fakat kitap incelemesini odağına alan yukarıda belirtilen çalışmalar ders kitaplarındaki içeriklerin matematik tarihinin farklı kullanımlarını örneklemede yetersizliğini vurgulamaktadır. Diğer taraftan, genel olarak matematik tarihini derslere entegre etmenin etkilerini inceleyen çalışmalar büyük ölçüde olumlu sonuçlar vermiştir. Ayrıca öğretmenlerin derslerinde matematik tarihi kullanma konusunda sahip oldukları düşüncelerin neler olduğunu konu edinen çalışmaların genelinde, öğretmenlerin derslerinde matematik tarihi kullanmalarını olumlu ve olumsuz anlamda etkileyen faktörlerin neler olduğu vurgulanmaktadır. Yapılan bu araştırmalar öğretmenlerin bilgi ve tecrübe eksikliği nedeniyle derslerinde matematik tarihini kullanmada zorluk yaşadıklarını (Panasuk ve Horton, 2012; Weng Kin, 2008) göstermektedir. Ek olarak, öğrencileri ulusal sınavlara hazırlama kaygısı, matematik tarihi ile ilgili kaynaklara erişimdeki sınırlııklar, sınıf kontrolünün zorlaşması ve öğretmenlerin matematik ile tarihi ilişkilendirememesi gibi konular matematik tarihinin derslerde kullanımını azaltan faktörler arasındadır (Carter, 2006; Panasuk ve Horton, 2012; Yıldız ve Baki, 2016). Örneğin, Hatisaru, Erbaş ve Çetinkaya (2011) öğretmenlerin matematik derslerinde tarih kullanımının öğrencilerin matematiksel düşüncelerine katkı sunacağı düşüncesine inanmadıkları sonucuna varmıştır.

Matematik tarihi ile ilgili alan yazın incelendiğinde öğretmen adaylarını merkeze alan çalışmaların sınırlı sayıda olduğu dikkat çekmektedir (Alpaslan, 2011; Genç ve Karataş, 2018; Yenilmez, 2011). Örneğin, kapsamlı bir doktora çalışmasında, Alpaslan (2011) 1593 ilköğretim matematik öğretmeni adayının matematik tarihi ile ilgili bilgilerini ve matematik tarihi kullanımına yönelik tutumlarını ve inanışlarını öğretmen eğitimi programındaki sınıf düzeyi ve cinsiyet bileşenlerine göre incelemiştir. Araştırma sonucunda, öğretmen adaylarının öğretmen eğitimi programında sınıf düzeyleri arttkç̧a matematik tarihi bilgilerinin ve matematik tarihini kullanmaya yönelik tutum ve inanışlarının arttğı ortaya çıkarmıştı. Bu nedenle, araştırmacı öğretmen adaylarının matematik tarihi ile ilgili edindikleri tecrübeler ve aldıkları dersler sonucunda bu konuda sahip oldukları bilgilerin, tutum ve inanışlarının iyileştiği yönünde bir çıkarıma ulaşmıştr. Diğer taraftan, Gönülateş (2008) matematik tarihini matematik öğretimi dersine entegre ederek öğretmen adaylarının matematik tarihi kullanma ile ilgili tutumlarını incelemiştir. Fakat çalışmada elde edilen sonuçlar, öğretmen adaylarının ders sonunda matematik tarihi kullanımı ile ilgili tutumlarında istatistiksel olarak anlamlı bir fark çıkmadığını göstermiştir. Çalışmaların sonuçlarındaki bu farklııklar, öğretmen adaylarının matematik tarihi ile ilgili algılarını içeren derinlikli çalışmalara intiyaç olduğunu göstermektedir. Yapılan nicel çalışmalar öğretmen adaylarının matematik tarihi ve kullanımı ile ilgili algıları konusunda her ne kadar genel bir resim sunsa da bu konuda derin bilgilere ulaşma ve çıkarımlarda bulunma adına yeterli olmayabilir.

Öğretmen adaylarının öğretecekleri matematiksel kavramların tarihsel gelişimine aşinalık kazanmaları, onlara matematik öğretimi konusunda etkili pedagojik yöntemler geliştirme ve kullanma firsatları sunar (Furinghetti, 1997). Bu nedenle, öğretmenlerin ve öğretmen adaylarının matematik tarihinin kullanımı için ortaokul düzeyindeki matematiksel kavramların ardında yatan temel tarihsel bilgiler ve gelişimler ile ilgili donanımlı olması gerekmektedir (Fried, 2001). Bu bakımdan, öğretmen adaylarına mesleki hayatlarına aktif anlamda başlamadan önce matematik tarihinin matematiği öğrenme ve öğretmedeki potansiyel rollerini açıklamak için öğretmen eğitimi programları en uygun yerlerden biridir 
(Freudenthal, 1981). Ancak öğretmen yetiştirme programları, öğretmen adaylarına matematik tarihi ile ilgili yeterli eğitim sunma konusunda ulusal (ör. Alpaslan ve Haser 2012) ve uluslararası çalışmalarda eleştirilmektedir (ör. Fauvel, 1991; Furinghetti, 1997). Alpaslan ve Haser (2012) Türkiye'de öğretmen yetiştirme programları kapsamında verilen Matematik Tarihi dersinin pedagojik bağlantlar anlamında kopukluklar içeren bir yapıya sahip olduğunu dile getirmektedir. Çünkü ders içeriklerinde matematik tarihi yalıttk tarihsel bilgiler (ör. formüller, bilim insanlarının biyografileri ve uygarlıklarda matematik kavramların gelişimleri) olarak sunulmaktadır. Maalesef bu ders içeriklerinde matematik tarihinin ilköğretim matematik seviyesinde nasıl kullanılacağına hiç vurgu yapılmamaktadır (Alpaslan, 2011; Alpaslan ve Haser, 2012). 2018 yılında Yüksek Öğretim Kurumu [YÖK] (2018) öğretmen yetiştirme lisans programlarını yenileyerek Matematik Tarihi dersi ile ilgili önemli kararlar almıştı. Bu doğrultuda, yenilenen lisans programlarında Illköğretim Matematik Öğretmenliği Bölümü için Matematik Tarihi Dersi dördüncü sınıftan birinci sınıfa alınmıştr. Ayrıca Matematik Tarihi dersi bir Genel Kültür dersi olmaktan çıkarılarak bir Alan Eğitimi Dersi olarak sınıflandırılmıştır. Gerek ders kitaplarında matematik tarihine yer verilmesi gerek lisans programında Matematik Tarihi dersi için yapılan değişimler ülkemizde matematik tarihine matematik öğrenme ve öğretme süreçleri adına verilen önemi göstermektedir. Fakat lisans programı içeriğinde Matematik Tarihi dersi halen matematik tarihinin öğretimde kullanımıyla ilgili pedagojik boyutta önemli eksikler içermektedir. Çünkü ilköğretim Matematik Öğretmenliği Lisans Programı'nda verilen matematik tarihi dersi içerikleri incelendiğinde öğretmen adaylarına matematik tarihini derslerinde nasıl kullanacaklarına ve ne gibi pedagojik firsatlara yer verilmesi gerektiğine dair açıklamaların olmadığı görülmektedir (Alpaslan ve Haser, 2012; YÖK, 2013; 2018). Bu araşttrmada, alan yazında matematik tarihinin öğretmen yetiştirme programlarında sadece amaç olarak değil aynı zamanda araç olarak da ele alınması konusundaki öneriler ve duyuşsal anlamda detaylı çalışmalara olan ihtiyaç göz önünde bulundurulmuştur. Bu nedenle, bu çalışmada öğretmen adaylarına matematik tarihi ile ilgili pedagojik deneyimler yaşamalarına firsat veren bir Matematik Tarihi dersi hazırlanarak, onların sahip oldukları matematik tarihi bilgileri ile algılarının neler olduğu ve bu algıların matematik tarihinin kullanımıyla ilgili pedagojik deneyimler yaşandıktan sonra nasıl değişim gösterdiği incelenmiştir. Özel olarak, şu araştrrma sorularına cevap aranmıştır:

- Illköğretim matematik öğretmeni adayları Pedagojik Deneyimler içeren Matematik Tarihi dersi öncesinde ve sonrasında matematik öğretmenlerinin matematik tarihi bilmesi konusunda neler düşünmektedir?

- Illköğretim matematik öğretmeni adaylarının Pedagojik Deneyimler içeren Matematik Tarihi dersi öncesinde ve sonrasında kendi sahip oldukları matematik tarihi bilgileriyle ilgili algıları nelerdir? Bu algılarda ne tip değişimler gerçekleşmiştir?

\section{Matematik Tarihinin Farklı Kullanım Biçimleri}

Jankvist (2009) yapılan bazı kapsamlı çalışmaları (ör. Tzanakis ve Arcavi, 2000) referans alarak matematik tarihinin matematik eğitiminde kullanımı için amaç olarak kullanma ve araç olarak kullanma adı altında iki temel kategori sunmuştur (Bkz. Tablo 1). Matematik tarihinin araç olarak kullanımı, öğrencileri güdüleme veya öğretilecek konuyu daha etkin hale getirme amaçları gütmektedir. Diğer bir deyişle, matematik tarihinin araç olarak kullanıldığı durumlarda öğrencileri motive etmek ve onların akademik başarılarını arttırmak amaçlanmaktadır. Diğer taraftan, matematik tarihi matematiğin çağlar boyunca uğradığı değişimleri göstermek, farklı kültürlerin matematiğin gelişimi üzerindeki etkilerini anlatmak ve gelişimlerin/değişimlerin insan ürünü olduğunu vurgulamak için kullanılıyorsa bu durumda matematik tarihi bir amaç olarak ele alınmaktadır.

\section{Tablo 1. Matematik tarihinin matematik eğitimindeki farklı kullanımları}

\section{Matematik tarihinin kullanım biçimleri Açıklama}

Araç olarak kullanma Matematiksel bir içeriğin öğretimi için kullanma

Matematikçilerin yaptı̆ı yanlışlar ile öğrencilere duyuşsal destek sağlama

Modern ve eski çözümleri kıyaslayarak olumlu ve olumsuz yönleri ortaya koyma

Farklı kültürler tarafindan kullanılan farklı çözüm ve ispat yaklaşımlarını gösterme ve öğrenmeyi desteklemek için uygun olanı seçme

Amaç olarak kullanma Matematiğin diğer disiplinlerle ilişkilerini gösterme ve tartışma

Matematiğin insan ürünü olduğunu vurgulama

Matematiksel kavram ve notasyonların gelişim sürecini gösterme

Tarihsel, epistemolojik ve sosyolojik vurgular yapma 
Matematik tarihinin öğretim süreçlerinde amaç ve araç olarak kullanımına ek olarak, derslerde matematik tarihine hangi yollarla yer verilebileceğine dair detaylı gruplamalara da rastlanmaktadır (Fried, 2001; Jankvist, 2009; Tzanakis ve Arcavi, 2000). Örneğin, Tzanakis ve Arcavi (2000) matematik tarihinin öğrenme ve öğretme süreçlerinde şu biçimlerde kullanılabileceğini belirtmiştir: tarihsel ufak parçalar/anekdotlar, tarihsel içerikli araştırma projeleri, tarihsel orijinal notlar, çalışma kağıtları, tarihsel paketler, tarihsel problemler, oyunlar, film ve diğer görsel materyaller, okul dışı deneyimler, internet ve matematikçilerin hatalarından faydalanma. Böylece ondan fazla yolla matematik tarihine derslerde yer verilebileceğini vurgulamışlardır. Bu gruplamanın genişliğini fark ederek, Jankvist (2009) yaptığı teorik çalışmada, matematik tarihinin derslerde kullanımına yönelik üç yaklaşım ortaya çıkarmıştır. Bunlar (i) aydınlatma yaklaşımı, (ii) modül yaklaşımı ve (iii) tarih tabanlı yaklaşım olarak isimlendirilmiştir. Aydınlatma yaklaşımı, matematik tarihine öğretim programında değişik kapsam ve ölçülerde yer verilmesini içerir. Örneğin, tarihsel ufak parçalar, ünlü bazı matematikçiler, onların buluşları ve hayatları ve tarih şeritleri belirtilen tarihsel ufak kesitler olarak düşünülebilir (Jankvist, 2009; Tzanakis ve Arcavi, 2000). Ülkemizde ortaokul kitaplarının içeriğinde en fazla matematik tarihi kullanım biçiminin de bu yönde olduğu görülmektedir (Baki ve Bütüner, 2013; Erdoğan, Eşmen ve Fındık, 2015; Mersin ve Durmuş, 2018). Modül yaklaşımı ise matematik tarihinin yer verildiği üniteler veya ders paketleri olarak düşünülebilir. Bu tarihsel paketler bir konunun öğretiminin tümünü (10-20 saat) kapsayabilmekle birlikte belirlenen iki saatlik bir süreyi de kapsayabilmektedir. Öğretimsel süreçte öğretim programının dışına çıkmadan tarihsel matematik içeriklerinin kullanımını kapsar. Ayrıca modül içeriğinde orijinal tarihi kaynaklar, oyunlar, dramalar, internet, tarihsel materyaller, çalışma yaprakları vs. kullanılabilir. Son olarak, tarih tabanlı yaklaşım diğer iki yaklaşımdan farklı olarak doğrudan matematik tarihi ve matematiğin tarihsel gelişim süreçlerine dayanmaktadır. Bu süreçte tarihsel gelişim açık bir şekilde tartş̧ımaz. Onun yerine, kavramların gelişimi olduğu gibi incelenir. Örneğin, sayı kümelerinin gelişimsel süreci doğal sayılarla başlanarak sayıların gelişimsel sürecine sadık kalınarak ele alınır (Jankvist, 2009). Bu araştırmada, belirtilen teorik çalışmalar ışığında öğretmen adaylarına hazırlanan lisans dersi içeriğinde matematik tarihinin hem bir araç hem de bir amaç olarak ne biçimlerde kullanılabileceğiyle ilgili bilgilere ve örneklere yer verilmiştir.

\section{Yöntem}

Araştırma sorularının yapısı ve veri toplama ve analiz teknikleri düşünüldüğünde araştırmanın genel yapısı nitel araştırma yöntemine daha uygun bulunmuştur. Özel olarak, bu çalışma öğretmen adaylarının kendi matematik tarihi bilgileriyle ilgili algılarının neler olduğunu ve bu algıların Pedagojik Deneyimler içeren Matematik Tarihi dersi sonrasında nasıl değiştiğini keşfetmeyi amaçlamaktadır. Bu nedenle, bu araştırma keşifsel durum çalışması (exploratory case study) niteliği taşımaktadır.

\section{Katılımcılar ve Bağlam}

Araştırmaya Türkiye'de bir devlet üniversitesinin İlköğretim Matematik Öğretmenliği Programı́nın son sınıfinda öğrenim gören 32 öğretmen adayı (28 kadın ve 4 erkek) katılmıştır. Katılımcılar ulaşılabilir örneklem seçme yöntemine göre belirlenmiştir. Hem araştırmacılar açısından kolay ulaşılabilir olması hem de 14 haftalık bir ders süreci içinde veri toplamaya elverişli şartları taşımaları nedeniyle bu örneklem yöntemi seçilmiştir. Öğretmen adaylarının son sınıf öğrencileri olmaları ise verilen Matematik Tarihi ders içeriğinin son sınıfta yer alması ile ilgilidir. Öğretmen adayları, illköğretim Matematik Öğretmenliği Lisans Programının üçüncü yılında Bilim Tarihi isimli zorunlu bir dersi almışlardır. Bilim Tarihi dersi içeriğinde şu konular ele alınmaktadır: Bilimin eski Yakındoğu uygarlıklarından şimdiye kadar geçirdiği evrim; l̇yonya-Helen, İslam-Türk (Arap, Horasan, Selçuk, Endülüs, Osmanlı) dönemlerinde bilim; bu dönemlerde ve Rönesans'tan şimdiye kadar batıda Astronomi, Matematik, Fizik, Tıp, Biyoloji vb. bilim dallarının gelişimi; 20. yüzyıl bilim ve teknoloji devrimleri.

Türkiye'de 2007 yılına ait öğretmen eğitimi programında Matematik Tarihi dördüncü sınıfin ilk döneminde bir Genel Kültür dersi olarak ele alınmaktadır. İçeriğinde öğretimi hedeflenen konular Tablo 2'de açıklanmıştır. Görüldüğü üzere, 2007 yılına ait öğretmen eğitimi programında öğretmen adaylarına matematik tarihi ile ilgili kazandırılması hedeflenen konular matematik eğitiminde tarihi bir genel kültür bileşeni olarak ele alırken öğretimsel/pedagojik olarak ele almamaktadır. 2018 yılında yenilenen öğretmen yetiştirme lisans programları kapsamında ise illköğretim Matematik Öğretmenliği Lisans Programı'nda Matematik Tarihi dersi birinci sınıfın ilk dönemine alınmıştr. Ek olarak, Matematik Tarihi dersi bir Genel Kültür dersi olmaktan çıkmış ve bir Alan Eğitimi dersi olarak sınıflandırılmıştır. Fakat Tablo 2'de sunulan 2018 Matematik Tarihi ders içeriği incelendiğinde matematik tarihi dersinin sadece matematiksel kavramların medeniyetler boyunca nasıl ele alındığı gibi bilgileri içerdiği görülmektedir. Diğer bir deyişle, yenilenen lisans programında da matematik tarihi kapsamında ele alınan bir derste öğretmen adaylarının matematik tarihini ilköğretim matematiğiyle bütünleştirmesi ve öğrencilerini bilişsel ve duyuşsal olarak desteklemede matematik tarihini pedagojik olarak ele alması pek mümkün görünmemektedir. Oysa yapılan uluslararası birçok çalışmada öğretmen adaylarının bilgilerini 
arttrmada matematik tarihinin matematik öğretimine entegrasyonunun önemi vurgulanmaktadır (ör. Jankvist, 2009). Bu nedenle, bu çalışmada matematik tarihinin öğretim programındaki içeriği ve uluslararası alan yazının bu konudaki önerileri göz önünde bulundurularak Matematik Tarihi ders içeriğinde bazı değişiklikler yapılmıştır.

\section{Tablo 2. İlköğretim Matematik Öğretmenliği Lisans Programı Matematik Tarihi ders içerikleri}

\begin{tabular}{|c|c|c|c|}
\hline Program & Yıl-Dönem & Niteliği & Matematik Tarihi Ders İçeriği \\
\hline $\begin{array}{l}\text { 2007-İlköğretim Matematik } \\
\text { Öğretmenliği Lisans Programı }\end{array}$ & $\begin{array}{l}\text { 4.Sınıf-1. } \\
\text { Dönem }\end{array}$ & $\begin{array}{l}\text { Genel Kültür } \\
\text { Dersi }\end{array}$ & $\begin{array}{l}\text { M.Ö. } 50000 \text { yıllarından başlayarak aritmetiğin gelişimi ve işlem- } \\
\text { ler. Geometri, alanlar, katılar, analitik geometri, modern geo- } \\
\text { metri, geometri araçları, cebir, denklemler, Binom teoremi, lo- } \\
\text { garitma, trigonometri, ölçüler, metrik sistem, kümeler, integral, } \\
\text { bilgisayarlar, sayılar, yapılar, denklem çözme, vektörler ve grafik- } \\
\text { ler gibi konularda, matematik üzerine yapılan çalışmalar ve bu } \\
\text { çalışmaları yapan matematikçilerin bibliyografileri (YÖK, 2007) }\end{array}$ \\
\hline $\begin{array}{l}\text { 2018-illköğretim Matematik } \\
\text { Öğretmenliği Lisans Programı }\end{array}$ & $\begin{array}{l}\text { 1.Sınıf-1. } \\
\text { Dönem }\end{array}$ & $\begin{array}{l}\text { Alan Eğitimi } \\
\text { Dersi }\end{array}$ & $\begin{array}{l}\text { Matematik tarihinin matematik eğitimindeki yeri; Eski Mısır ma- } \\
\text { tematiği; Eski Yunan matematiği; Uzak Doğu matematiği; İslam } \\
\text { dünyası matematikçileri; çağdaş matematiğin doğuşu; matema- } \\
\text { tiksel kavramların tarihsel gelişimi (YÖK, 2018) }\end{array}$ \\
\hline
\end{tabular}

Dersin ilk 9 haftasında Tablo 2'de sunulan matematik tarihi içerikleri ele alınmıştır. Bu derslerde ayrıca, öğretmen adaylarına, dersin içeriğine paralel olacak şekilde matematik tarihinin matematik öğretiminde kullanımına yönelik örnekler ve matematik tarihi entegrasyonuna örnek teşkil eden farklı matematik öğrenme alanlarıyla ilgili tez çalışmalarından ders planları (Albayrak, 2011; Başıbüyük, 2012; Bayam, 2012; Gürsoy, 2010; Kaşıkçı, 2015; Tözlüyurt, 2008) gösterilmiştir. Sunulan örneklerin bazıları Şekil 1'de gösterilmiştir. Öğretmen adaylarına gösterilen örneklerin seçiminde şu hususlara dikkat edilmiştir: (i) ilköğretim matematik öğretmenliği öğretim programı hedef ve kazanımları içinde tanımlanmış konularla ilgili olması ve (ii) farklı öğretimsel yöntemlere firsat sunması veya modern matematiğin taşıdığı gösterim/notasyon kolaylığını vurgulayabilecek örnek içeriğine sahip olması. Bu sayede örneklenen durumlar matematik tarihinin genel kültür edinme rolüne ek olarak matematik tarihinden öğretimde yararlanılması açısından da öğretmen adaylarına sunulmaya çalışılmıştr. Böylece öğretmen adayları, matematik tarihinin ders içeriklerinde farklı kullanımlarına ilişkin (ör. ufak kesitler, ders planları vb.) fikir sahibi olmuşlardır.

a. İrrasyonel uzunlukların çizimi

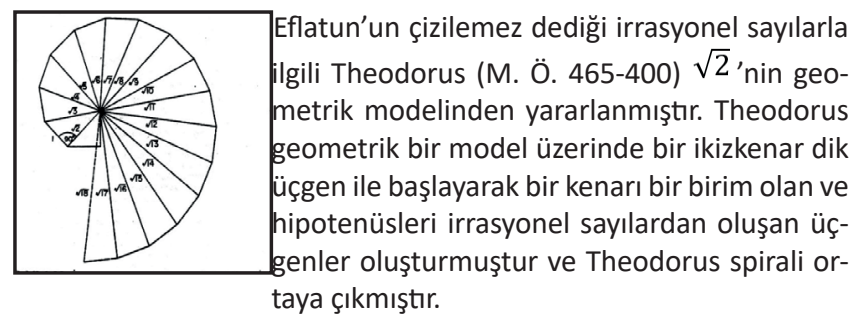

c. Hiyeroglif sayılarla toplama işlemi

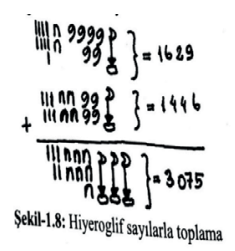

Hiyeroglif sayılarda toplama işleminde sayılar soldan sağa doğru yazılarak basamak değerlerine göre toplama yapılırdı. Basamaklar için özel işaretler kullanılırdı. Örneğin, şu anda kullandığımız sayı sisteminde dört basamaklı bir sayıda birler basamağındaki 9 rakamı, Hiyerog-

lif gösterimde ilk başta ve birler basamağının sembolü olan çubuk işaretinin 9 kez kullanılmasıyla belirtilirdi. b. Babillerin çemberin çevresini hesaplaması

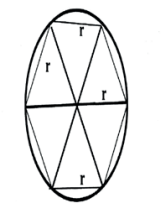

Bu örnekte Babillerin çemberin çevresini hesaplamada kullandıkları yöntem yer almaktadır. Babiller, çemberin çapı $2 r$ ve düzgün altgenin çevresi $6 r$ olmak üzere $6 r / 2 r=3$ oranını bulmuşlardır. Bu sayede, çemberin çapı bilindiğinde çevresini tahmin etmişlerdir. Daha

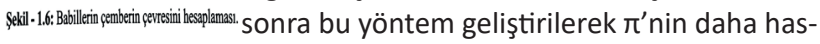
sas tahminleri için kullanılmıştır.

d. Şabakah yöntemi ile çarpma işlemi

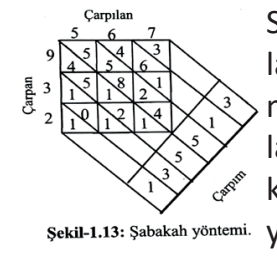

Sayılarında sıfir olmadığı için basamakları boş bırakan Hintlilerin çarpma işlemi çok karışıkt. Buna karşın Müslümanlar, sıfirı ilave ederek çarpma işlemini kafes yöntemi olarak bilinen şabakah yöntemiyle yapmışlar. Bu yöntemde satır ve sütuna çarpan ve çarpılan sayılar şekildeki gibi yazıldıktan sonra satırdaki bir sayının sütundaki sayı ile çarpım sonucu çizilen kafesin içine yazılmıştır.

\section{Şekil 1. Matematik tarihi dersinde sunulan bazı örnekler (Baki, 2014)}

10. ve 11. haftada ise öğretmen adaylarından ilköğretim matematik ders kitaplarını öğrenme alanlarına göre içeriğindeki matematik tarihinin neler olduğu ve nasıl kullanıldığı bakımından incelemeleri ve bu inceleme raporlarını sınıfta sunmaları istenmiştir. Bu inceleme için bir ders kitabı incelemesi şablonu kullanılmıştı. Bu şablon Baki ve Bütüner'in (2013) çalışmasından adapte edilmiştir. Bu şablon, matematik tarihi kullanım yolu (ör. ufak kesitler, bibliyografiler, kısa yazılar, tarihsel gösterimler gibi ve aydınlatma/modül ve tarih tabanlı yaklaşımlar) ve sınıf düzeyi, konu-alt konu-kazanım, sayfa numarası, içerik, matematik tarihinin nasıl kullanıldığı (araç vs. amaç), kullanıldığı yer (konunun girişi vs.) ve örnekler olmak üzere yedi kategoriden oluş- 
muştur. Öğretmen adaylarının bir grubunun hazırladığı ders kitabı matematik tarihi (MT) içerik analizi kesiti Tablo 3'te gösterilmiştir. Gruplar, farklı öğrenme alanları ve sınıf seviyelerine göre tüm ders kitaplarını paylaşarak analiz etmiş ve bu analizleriyle ilgili bilgileri derste sunmuşlardır. Sunumlarda, MT’nin inceledikleri kitap ve konularda nasıl ele alındığı sınıfça tartı̧ılmıştır.

Tablo 3. Öğretmen adaylarının kitaplardaki MT içerik analizi örneğinden bir kesit (Grup 4)

\begin{tabular}{|c|c|c|c|c|c|c|}
\hline $\begin{array}{c}\text { Kullanım } \\
\text { yolu }\end{array}$ & $\begin{array}{c}\text { Konu/Sınıf } \\
\text { düzeyi }\end{array}$ & $\begin{array}{c}\text { Sayfa } \\
\text { no. }\end{array}$ & İçerik & $\begin{array}{l}\text { MT kullanım } \\
\text { biçimi }\end{array}$ & $\begin{array}{c}\text { Kullanıldığı } \\
\text { yer }\end{array}$ & Örnekler \\
\hline $\begin{array}{l}\text { Tarihsel } \\
\text { Ufak Par- } \\
\text { çalar }\end{array}$ & $\begin{array}{l}\text { Sayılar ve } \\
\text { İşlemler - } \\
\text { Kareköklü } \\
\text { Sayılar } \\
\text { 8. sınıf }\end{array}$ & 49 & $\begin{array}{l}\text { Cebir'in } \\
\text { kurucusu }\end{array}$ & $\begin{array}{l}\text { Araç, çünkü } \\
\text { karekök ifa- } \\
\text { desinin Cabir } \\
\text { Bin Hayyam'ın } \\
\text { çalışmaları- } \\
\text { nın bir ürünü } \\
\text { olduğundan } \\
\text { bahsediyor. }\end{array}$ & $\begin{array}{l}\text { Konunun } \\
\text { sonu }\end{array}$ & $\begin{array}{l}\text { Cebir biliminin kurucusu kesin olarak bilinme- } \\
\text { mekle birlikte Arap matematikçi El Cabir Bin } \\
\text { Hayyam'dır. El Cabir, denklemleri çözerken } \\
\text { karekök ve küp kök almayı da göstermiştir. } \\
\text { Karekök sembolü “Ö " ilk olarak 16. Yüzyılda } \\
\text { kullanılmaya başlanmıştır. "Radix" kelimesi } \\
\text { Latincede kök demektir. Kök sembolünün de } \\
\text { "radix" kelimesinin baş harfi olan "r" den geldiği } \\
\text { düşünülmektedir. }\end{array}$ \\
\hline
\end{tabular}

Dersin son 3 haftasında (12., 13. ve 14. haftalar) ise öğretmen adayları kendilerine daha önceden atanan öğrenme alanları ile ilgili 2-3 kişilik gruplar halinde hazırladıkları matematik tarihi entegre edilmiş ders planlarını sunarak diğer grup arkadaşlarıyla tartışmalar gerçekleştirmişlerdir. Öğretmen adaylarının grupça hazırladıkları ders planlarının içerdiği konular, planlardaki MT içerikler ve MT'nin kullanım yerleri ve biçimleri Tablo 4'te özet olarak sunulmuştur.

Tablo 4. Matematik tarihinin kullanıldığı ders planları ile ilgili özet bilgiler

\begin{tabular}{|c|c|c|c|c|c|}
\hline Gruplar & Konu & Kapsam & MT içeriği & $\begin{array}{l}\text { Ders planı MT } \\
\text { kullanım yeri }\end{array}$ & $\begin{array}{l}\text { Kullanım } \\
\text { biçimi }\end{array}$ \\
\hline Grup 1 & $\begin{array}{l}\text { Sayılar ve } \\
\text { işlemler }\end{array}$ & $\begin{array}{l}\text { Doğal sayılarda çarpma iş- } \\
\text { lemi }\end{array}$ & Napier Çubuğu ve Şabakah Yöntemi & $\begin{array}{l}\text { Ders planı bütü- } \\
\text { nünde }\end{array}$ & Araç \\
\hline Grup 2 & $\begin{array}{l}\text { Sayılar ve } \\
\text { işlemler }\end{array}$ & $\begin{array}{l}\text { Bir doğal sayının kendisiyle } \\
\text { tekrarlı çarpımını üslü nice- } \\
\text { lik olarak ifade etme }\end{array}$ & $\begin{array}{l}\text { Buğday hikâyesini kullanarak üslü sayıların } \\
\text { öğretilmesi }\end{array}$ & $\begin{array}{l}\text { Ders planı bütü- } \\
\text { nünde }\end{array}$ & Araç \\
\hline Grup 3 & $\begin{array}{l}\text { Sayılar ve } \\
\text { işlemler }\end{array}$ & Tam sayılarla çarpma işlemi & $\begin{array}{l}\text { Negatif sayıların tarihsel gelişimi ve Mısırlılar- } \\
\text { da çarpma yöntemi }\end{array}$ & Giriş ve sonuç & Amaç \\
\hline Grup 4 & $\begin{array}{l}\text { Sayılar ve } \\
\text { işlemler }\end{array}$ & $\begin{array}{l}\text { Tam kare olmayan sayıların } \\
\text { karekök değerlerini belirme }\end{array}$ & Babillerin karekök hesaplama yöntemi & $\begin{array}{l}\text { Ders planı bütü- } \\
\text { nünde }\end{array}$ & Araç \\
\hline Grup 5 & Cebir & $\begin{array}{l}\text { Sözel/cebirsel olarak veri- } \\
\text { len bir duruma uygun ce- } \\
\text { birsel/sözel durum yazma }\end{array}$ & Harezmi'nin hayat (video) & Giriş & Araç \\
\hline Grup 6 & Cebir & Eşitliğin korunum ilkesi & $\begin{array}{l}\text { Harezmi'nin hayatı (video) ve eşitlik ve denk- } \\
\text { lem ile ilgili kullandığı yöntem ve Ali Kuş- } \\
\text { çu'nun İkili Yanlışlama ve Tahlil Yöntemleri }\end{array}$ & $\begin{array}{l}\text { Ders planı bütü- } \\
\text { nünde }\end{array}$ & Araç \\
\hline Grup 7 & Cebir & Cebirsel ifade & Arapça 'da x'in "şey" anlamı & Giriş & Amaç \\
\hline Grup 8 & $\begin{array}{l}\text { Geometri } \\
\text { ve ölçme }\end{array}$ & Dikdörtgen alan hesabı & Mısırlıların alan hesaplama yöntemi & Giriş & Amaç \\
\hline Grup 9 & $\begin{array}{l}\text { Geometri } \\
\text { ve ölçme }\end{array}$ & $\begin{array}{l}\text { Çemberin merkezini, yarı- } \\
\text { çapını ve çapını belirleme }\end{array}$ & $\begin{array}{l}\text { Platon, Pisagor, Arşimet, Öklid, ve Descar- } \\
\text { tes'in çember ifadeleri }\end{array}$ & Giriş & Amaç \\
\hline Grup 10 & $\begin{array}{l}\text { Geometri } \\
\text { ve ölçme }\end{array}$ & $\begin{array}{l}\text { Pisagor bağıntısını oluştur- } \\
\text { ma }\end{array}$ & Pisagor Teoremi & $\begin{array}{l}\text { Ders planı bütü- } \\
\text { nünde }\end{array}$ & Araç \\
\hline Grup 11 & Veri işleme & Sütun grafiği çizme & Matematikçilerin yaşadığı yüzyılların bilgisi & Giriş & Amaç \\
\hline
\end{tabular}

Tablo 4'te görüldüğü üzere, toplamda 11 tane ders planı hazırlanmıştır. Öğrenme alanlarının öğretim programındaki yoğunluklarına paralel olarak, dört ders planı sayılar ve işlemler, üç ders planı cebir, 3 ders planı geometri ve ölçme ve son olarak bir ders planı veri işleme öğrenme alanlarında hazırlanmıştı. Dağııımın bu şekilde olmasına araştırmacılar karar vermiştir. 6 grup matematik tarihini araç olarak kullanmıştr. Örneğin, Napier Çubuğu ve Şabakah Yönteminin kullanılmasıyla doğal sayılarda çarpma işlemi öğretimi (1.grup), buğday hikâyesini kullanarak üslü sayıların öğretimi (2.grup), tam kare olmayan sayıların karekök değerlerinin hangi iki doğal sayı arasında olduğunun Babil yöntemi ile belirlenmesi (4.grup) ile ilgili planlarda MT araç olarak kullanılmıştır. 5 grup ise MT'yi amaç olarak kullanmıştır. MT'yi ders 
planında araç olarak kullanan gruplar genelde ders planlarının tümüne bu kullanım biçimini yaymışlardır. Fakat MT'yi amaç olarak kullanan gruplar MT'yi ders planının giriş ve sonuç kısımlarında ufak tarihsel kesitler, anekdotlar veya video gibi araçlar ile ele almışlardır. MT'yi araç olarak ele alan gruplar genel olarak MT'yi bir içeriğin öğretimi, modern ve eski çözümleri kıyaslayarak olumlu ve olumsuz yönleri ortaya koyma ve farklı kültürler tarafindan kullanılan farklı çözüm ve ispat yaklaşımlarını gösterme amacıyla kullanmışlardır. Diğer taraftan, MT'yi amaç olarak kullanan gruplar MT'yi matematiğin bir insan ürünü olduğunu vurgulamak ve matematiksel kavram ve notasyonların gelişim sürecini göstermek için kullanmışlardır. Bu noktada, öğretmen adayları sadece konunun giriş kısmına dikkat çekme amaçlı matematik tarihi bilgisi koymuş ve daha farkıı bir tasarım düşünemediklerini belirtmiştir. Ders planlarını hazırlama sürecinde, öğretmen adayları, genellikle matematik tarihi kullanarak matematiksel kavram/kavramlarının öğretimini tasarlamakta zorlandıklarını ifade etmişlerdir. Ders planlarındaki MT kullanım örneklerinin bazıları ve ders plan hazırlama süreçleriyle ilgili katılımcı düşünceleri bulgular ve ekte (Ek-1) sunulmuştur.

\section{Verilerin Toplanması ve Analizi}

Bu araştırmada verilerin toplanmasında nitel veri toplama yöntemlerinden yararlanılmıştı ayrıca nicel anlamda frekans analizleri yapılmıştır. Illk olarak, öğretmen adaylarından matematik tarihi ve matematik tarihinin öğretimde kullanılması ile ilgili hazırlanan açık uçlu sorular için yazılı cevaplar alınmıştır. Bu sorularda, ilk olarak öğretmen adaylarından bir matematik öğretmeninin matematik tarihi bilmesi gerekip gerekmediği konusunda düşüncelerini gerekçelendirerek yazmaları istenmiştir. Ardından, öğretmen adaylarından sahip oldukları matematik tarihi bilgilerinin neleri içerdiğini ve kendi sahip oldukları matematik tarihi bilgisini eğer bir düzey olarak belirtmek isteseler hangi düzeyde bulduklarını tanımlamaları istenmiştir. Ders öncesi açık-uçlu sorulara verilen cevaplar alındıktan sonra, Pedagojik Deneyimler içeren Matematik Tarihi dersi bir önceki başlık altında belirtilen içerikler ile ele alınmıştır. Dersin tamamlanmasıyla birlikte öğretmen adaylarına aynı açık uçlu sorular tekrar sorulmuştur ve yazılı cevapları alınmıştır. Diğer taraftan, ders esnasında yapılan grup tartş̧maları ve dersin yürütücüsü olan araştırmacı tarafindan yazılı yorumlar not alınarak veriyi desteklemede kullanılmıştr. Verilerin analizinde nitel veri analizi yöntemlerinden içerik analizi yöntemi kullanılmıştır. Bu bağlamda, kodlar ve temalar doğrudan verilerin analiziyle ortaya çıkarılmıştı. Verilerin detaylı analizi için öncelikle tüm yazılı dokumanlar elektronik ortama geçirilmiştir. Öğretmen adaylarının öğretmenlerin matematik tarihi bilgisine sahip olması konusundaki düşünceleri olumlu ve olumsuz görüşe sahip olma durumlarına göre ikiye ayrılmıştır. Ardından, öğretmen adaylarının bu konuda sundukları gerekçeler incelenmiştir. Öğretmen adaylarının sundukları olumlu gerekçeler için dört grup ortaya çıkmıştı. Bunlar; (i) genel kültür ve saygınlık kazanma, (ii) konu alan bilgisini güçlendirme, (iii) öğretim sürecini güçlendirme ve (iv) öğrencileri matematiğe karşı duyuşsal olarak destekleme başlıkları altında toplanmıştır. Bu bileşenler aslında Jankvist'in (2009) matematik tarihinin amaç ve araç olarak kullanım gruplamasıyla benzerlik göstermektedir. Bu gruplamada genel kültür ve saygınlık kazanma ile konu alan bilgilerini güçlendirme bileşenleri matematik tarihini bir amaç olarak görme bileşenine uygunken, öğretim ve öğrenci boyutunda iyileştirmeler sağlamak için matematik öğretmenlerinin matematik tarihi bilmesi görüşü daha çok matematik tarihinin araç olarak kullanımı ile uygun görünmektedir. Tüm bu bileşenlerin içerikleri ve örnekleri bulgular kısmında sunulmuştur.

Öğretmen adaylarının matematik öğretmenlerinin matematik tarihi bilme konusundaki görüşleri alındıktan sonra, kendi matematik tarihi bilgileriyle ilgili sahip oldukları algılar incelenmiştir. Bu doğrultuda, kendi matematik tarihi bilgilerini nasıl tanımladıkları veriler ışığında üç gruba ayrılmıştı. Bu gruplar; (i) yüzeysel, (ii) orta derece ve (iii) derin olarak isimlendirilmiştir. Bu isimlendirmeler öğretmen adaylarının açık uçlu sorular için yazdıkları açıklamalar referans alınarak yapılmıştr. Ders-öncesi cevaplarda her bir öğretmen adayı için Matematik Tarihi (MT) bilgisi ile algısının nasıl olduğu not edilmiştir. Ardından, benzer şekilde öğretmen adaylarının açık uçlu sorular için sundukları ders sonrası yazııı açıklamalardaki MT bilgileriyle ilgili algıları gruplandırılmıştı. Son olarak, ders öncesi ve ders sonrası yazıı açıklamalar kıyaslanarak öğretmen adaylarının kendi MT bilgileri ile ilgili algılarındaki değişimler belirlenmiştir. Bu değişimler belli gruplar altında bulgularda (Bkz. Tablo 7) sunulduğu biçimiyle kategorize edilmiştir. Araştırmacılar, çalışmada elde edilen kod ve kategorilere göre verilerin tümünü ayrı ayrı analiz etmişlerdir. Bu analiz sonucunda kodlayıcılar arası uyum kontrol edilmiştir. Kodlayıcı uyum yüzdeleri öğretmen adaylarının öğretmenlerin MT bilme konusundaki fikirlerinde \%100 olarak hesaplanmıştır. Diğer taraftan, öğretmen adaylarının kendi bilgileriyle ilgili algılarının gruplama için yapılan kodlamalarda bu oran şu şekilde elde edilmiştir. Açık uçlu sorulara verilen ilk yazılı cevaplarda 32 öğretmen adayının algılarının kodlanmasında 27'si için ortak kanıya varılırken, son-yazılı cevaplarda ise 32 öğretmen adayının algılarının kodlanmasında 28'i için ortak kanıya varılmıştır. Bu durumda görüş birliği ve görüş ayrılığı içerikli Güvenirlik = (Görüş birliği) / (görüş birliği + Görüş ayrılı̆ı) formülüne göre açık uçlu soruların ilk-yazılı cevaplarının analizinde güvenirlik = $27 /(27+5)=0.84$ ve son-yazılı cevaplarının analizi- için güvenirlik $=28 /(28+4)=0.88$ hesaplanmıştır.

| Kastamonu Eğitim Dergisi, 27(6), 2019| 


\section{Bulgular}

Araştırmada edinilen bulgular, iki başlık altında sunulmuştur. İlk kısımda, öğretmen adaylarının matematik tarihini bilmesi konusundaki algılarının neler olduğu incelenmiştir. ỉkinci kısımda ise öğretmen adaylarının kendi matematik tarihi bilgileriyle ilgili algılarının pedagojik olarak zenginleştirilmiş matematik tarihi dersini almadan önce ve sonra nasıl olduğu sunulmuştur. Bu kısımda, ayrıca öğretmen adaylarııın bu konudaki algılarında ortaya çıkan değişimler gruplandırılarak sunulmuştur.

\section{Matematik Öğretmenleri Matematik Tarihi Bilmeli Midir?}

Öğretmen adaylarına "matematik öğretmenleri matematik tarihini bilmeli midir? Neden?" sorusu sorulduğunda MT-ders öncesi yazılı cevaplarda 32 öğretmenin 31'i matematik öğretmenlerinin matematik tarihini bilmesi gerektiğini düşündüğünü belirtmiştir. Sadece bir öğretmen adayı, ilköğretim düzeyindeki öğrencilerinin girdiği ulusal sınavlarda matematik tarihinin sorulmamasını gerekçe göstererek öğretmenlerin matematik tarihi bilgisine ihtiyacının olmadığını belirtmiştir. Fakat MT-ders sonrası yazılı cevaplarda öğretmen adaylarının tamamı öğretmenlerin matematik tarihi bilgisine sahip olması gerektiğini ifade etmişlerdir (Bkz. Tablo 5).

Tablo 5'te sunulan bilgilere göre, MT-ders öncesinde yazılan cevaplarda öğretmen adaylarının \%28'i öğretmenlerin genel kültür edinmek veya saygınlık kazanmak için matematik tarihi bilmesi gerektiğini düşünmüştür. Fakat bu oran MT-ders sonrasında yazılan cevaplarda \%9'a düşmüştür. Bu durum, öğretmen adaylarının matematik tarihi ile ilgili sahip oldukları algılar ile ilişkili görünmektedir. Örneğin, MT-ders öncesi yazılı cevaplarda öğretmen adaylarından biri şöyle bir cümle kurmuştur: "Öğretmenler matematik tarihi bilirse öğrencilerinin gözünde daha bilgili olurlar. Bu sayede öğrenciler öğretmenlerine daha çok saygı duyar (ÖA4)". MT-ders öncesi yazılı cevaplarındaki diğer bir grup yorumda ise öğretmen adayları şu açıklamaya benzer açıklamalar sunmuştur: "Matematik tarihi bilmek, öğretmenler için motivasyon kaynağı olabilir. Öğretmenler hem kendilerini geliştirirler hem de tarihsel örneklerde genel kültürlerini arttrabilirler (ÖA5)". Bu açıklamalar, öğretmen adaylarının MT-ders öncesi cevaplarında matematik tarihi bilme konusunda kültürel ve tarihsel açıdan bir bakış sunduklarını göstermiştir.

Tablo 5. Öğretmen adaylarının öğretmenlerin matematik tarihi bilmesi konusundaki düşünceleri

\begin{tabular}{|c|c|c|c|c|c|}
\hline \multirow{3}{*}{$\begin{array}{c}\text { Öğretmen adayının cevabı } \\
\text { Öğretmenler matematik tarihi bilmelidir }\end{array}$} & \multirow{3}{*}{$\begin{array}{c}\text { Öğretmen adaylarının gerekçeleri } \\
\text { Genel kültür ve saygınlık kazanma }\end{array}$} & \multicolumn{4}{|c|}{ Kişi sayısı (\%)* } \\
\hline & & \multicolumn{2}{|c|}{$\begin{array}{l}\text { MT-ders } \\
\text { öncesi }\end{array}$} & \multicolumn{2}{|c|}{$\begin{array}{c}\text { MT-ders } \\
\text { sonrası }\end{array}$} \\
\hline & & 9 & $(28)$ & 3 & (9) \\
\hline \multirow{3}{*}{ Ogretmenler matematik tarihi bilmelidir } & Konu alan bilgilerini güçlendirme & 11 & (34) & 11 & (34) \\
\hline & Öğretim sürecini güçlendirme & 31 & (97) & 20 & (63) \\
\hline & Öğrencilere duyuşsal destek sunma & 19 & (54) & 27 & (84) \\
\hline $\begin{array}{l}\text { Öğretmenlerin matematik tarihi bilmesine } \\
\text { gerek yoktur }\end{array}$ & Sınavlarda yer verilmemesi & 1 & (3) & 0 & 0 \\
\hline
\end{tabular}
*Not. Tablodaki tüm yüzdeler katılımcı sayısı olan 32'ye göre hesaplanmıştır.

Öğretmenlerin matematik tarihini neden bilmesi gerektiği konusunda öğretmen adaylarının \%34'ü hem MT-ders öncesi yazılı cevaplarında hem de MT-ders sonrası yazıı ı cevaplarında konu alan bilgisini güçlendirmeyi gerekçe olarak sunmuştur. Örneğin, ÖA1, MT-ders öncesi yazılı cevabında "öğretmenler matematiksel kavramların altında yatan derin anlamları anlamak için matematik tarihini bilmelidir. Bu sayede kendilerini bilgileri açısından daha yeterli hissedebilirler." açıklamasını sunmuştur. Benzer şekilde, MT-ders sonrası yazılı cevapta ÖA17 de öğretmenlerin öğreteceklerinin ötesinde matematik bilmesi gerektiğini düşündüğü için matematik tarihi bilgisine hakim olması gerektiğini vurgulamıştır. Sonuç olarak, öğretmen adaylarının belli bir kısmı öğretmenlerin sahip oldukları matematik bilgisine derinlik katma bakımından matematik tarihi bilmesinin faydalı olacağına inanmaktadır.

Diğer ilginç bir bulgu ise öğretmen adaylarının \%96'sının MT-ders öncesi yazılı cevaplarında matematik tarihi bilmenin matematik öğretim sürecini güçlendirmek için gerekli olduğu yönündeki düşünce olmuştur. Bu nokta öğretmen adaylarının bazılarının yazılı açıklamaları aşağıda sunulmuştur:

"Matematik, sadece bir işlem topluluğu değildir. Matematiği tarihsel gelişimlerini anlamadan pratik yaparak ögretmenin iyi bir yol olduğunu düşünmüyorum. Örneğin, sıfir, yokluk anlamına gelir. Ancak sifirın nasıl keşfedildiğinden bahsetmeden bu sayının çarpımdaki yutan elaman olduğunu söylemek bana mantıklı gelmiyor. Bu nedenle, etkili bir öğretim için öğretmenler matematiğin tarihsel gelişimini bilmelidir" [MTders öncesi düşünceler, ÖA8]. 
Matematik tarihi bilmenin matematik öğretim sürecini güçlendirmek için gerekli olduğunu düşünen öğretmen adaylarının oranı MT-ders sonrası yazılı cevaplarda \%63 olarak tespit edilmiştir. Her ne kadar bu oran azalmış gibi görünse de sayısal olarak öğretmen adaylarının büyük bir çoğunluğunun matematik tarihinin öğretim sürecindeki rolüne odaklandıkları söylenebilir. Örneğin, MT-ders sonrası yazılı cevabında, ÖA7 "eğer öğretmenler matematik tarihi bilirse bir kavramı öğretirken tarihte kullanılan yöntemleri düşünerek en uygun öğretimsel yaklaşımı seçebilirler." açıklamasına yer vermiştir. Diğer bir öğretmen adayı olan ÖA9 ise " öğretmenler matematik tarihini iyi bilirse öğrencilerinin hangi konularda ne gibi zorluklar yaşayacağını da bilirler. Bu sayede öğrencilerin ihtiyaçlarına göre etkili öğretim yapabilirler." açıklamasını sunmuştur. Son olarak, Tablo 3'te görüldüğg̈ üzere MT-ders öncesi yazılı cevaplarda öğretmen adaylarının \%54'ü öğretmenlerin öğrencilerini matematik dersine karşı duyuşsal olarak desteklemek için matematik tarihi bilmesi gerektiğini belirtmiştir. Bu oran, MT-ders sonrası yazılı cevaplarda \%84'e yükselmiştir. Bu oranlardaki değişimler öğretmen adaylarının matematik tarihi bilme konusundaki algılarının matematik tarihi dersinin alınmasıyla birlikte öğretmen-odaklı faktörlerden (konu alan bilgisi, saygınlık kazanma ve genel kültür edinme) öğrenci-odaklı faktörlere (öğrenmeyi destekleme, öğrencileri motive etme) kaydığına işaret etmektedir. Öğretmen adayları özellikle öğrencilere matematiğe karşı olumlu tutum ve inanış kazandırma, öğrencileri derse güdüleme, öğrencilerin öz-yeterlilik algısını geliştirme ve matematiğe olan ilgilerini arttırma gibi noktalarda matematik tarihi bilmenin önemli olduğunu vurgulamışlardır. Bu durumlarla ilgili bazı cevaplar şu şekildedir:

“Öğrenciler derslerde her zaman bu formül nereden geldi? Matematik ögrenmek benim ne işime yarayacak? gibi sorular soruyorlar. Matematik tarihi bilen bir ögretmen ögrencilerin bu sorularına cevap verebilir. Bu açıklamalar ise öğrencilerin matematiğin bir insan çabası olduğunu anlamasını sağlar. Bu da onların derse olan ilgilerini arttırabilir" [MT-ders sonras1 düşünceler, ÖA28].

“Öğrenciler matematiği genelde sıkıcı ve zor buluyorlar. Öğretmenler matematik tarihi bilirse dersleri daha eğlenceli hale getirebilir. Bu da öğrencilerin matematiğe karşı olumlu tutum kazanmalarını să̆lar. Fakat sunulacak içerik kesinlikle ögrenciyi sıkmayacak şekilde olmalıdır " [MT-ders sonrası düşünceler, ÖA23].

Belirtilen yorumlar, öğretmen adaylarının matematik tarihini öğrencileri matematiğe karşı duyuşsal olarak destekleme adına araç olarak gördüklerini göstermektedir.

\section{Bir Matematik Öğretmen Adayı Olarak Ben Ne Kadar Matematik Tarihi Biliyorum?}

Öğretmen adaylarının kendi matematik tarihi bilgileriyle ilgili algıları, Tablo 6'da sunulduğu gibi üç gruba ayrılmıştr. Ayrıca bu tabloda öğretmen adaylarının yazılı açıklamalarının içeriği ve ders esnasında sınıfta yaptıkları açıklamalar dikkate alınarak, öğretmen adaylarının neye göre kendi matematik tarihini yüzeysel, orta derece ve derin olarak isimlendirdikleri sunulmuştur.

Tablo 6. Öğretmen adaylarının kendi matematik tarihi (MT) bilgileriyle ilgili algıları

\begin{tabular}{|c|c|c|c|c|c|}
\hline \multirow{2}{*}{$\begin{array}{l}\text { MT bilgisi ile } \\
\text { ilgili algılar }\end{array}$} & \multirow{2}{*}{ MT’nin ne derece bilindiğini belirtmek için yapılan açıklamaların içeriği } & \multicolumn{4}{|c|}{ Kişi sayısı (\%) } \\
\hline & & & $\begin{array}{l}\text {-ders } \\
\text { cesi }\end{array}$ & & $\begin{array}{l}\text { ders } \\
\text { irası }\end{array}$ \\
\hline Yüzeysel & $\begin{array}{l}\text { Sadece bazı formül/teorem ve ünlü matematikçilerin ismini bildiklerini belirtmiş- } \\
\text { lerdir. }\end{array}$ & 16 & (50) & 0 & 0 \\
\hline Orta derece & $\begin{array}{l}\text { Bazı önemli matematiksel buluşları ve bu buluşları yapan matematikçilerin (ör. } \\
\text { Pisagor) yaşam hikayelerini bildiklerini ve bazı medeniyetlerdeki (ör. Mısırlılar, Ba- } \\
\text { biller) matematiksel gelişmeleri veya bazı matematik kavramlarının (ör. Sayılar) } \\
\text { gelişimsel süreçleriyle ilgili bilgi sahibi olduklarını belirtmişlerdir. }\end{array}$ & 12 & (38) & 29 & (90) \\
\hline Derin & $\begin{array}{l}\text { Bazı önemli matematiksel buluşları ve bu buluşları yapan matematikçilerin (ör. } \\
\text { Pisagor) yaşam hikayelerini, bazı medeniyetlerdeki (ör. Mısırlılar, Babiller) ma- } \\
\text { tematiksel gelişmeleri veya bazı matematik kavramlarının (ör. sayılar) gelişimsel } \\
\text { süreçleriyle ilgili bilgi sahibi olduklarını belirtmişlerdir. Bunlara ek olarak, diğer } \\
\text { birçok matematik konu ve kavramlarının gelişimsel süreçlerini ve matematiksel } \\
\text { kavramların diğer disiplinlerdeki kullanımlarına ilişkin bilgilerini ve duydukları ilgiyi } \\
\text { belirtmişlerdir. Bu bileşendeki bilgi düzeyine sadece öğrenme yaşantısı boyunca } \\
\text { değil çeşitli dergiler (ör. Matematik Tarihi), kitaplar ve dijital kaynaklar aracılığıyla } \\
\text { da eriştiklerini belirtmişlerdir. }\end{array}$ & 4 & (12) & 3 & (10) \\
\hline
\end{tabular}

Öğretmen adaylarının MT-ders öncesi yorumları incelendiğinde \%88'inin kendi matematik tarihi bilgisini genel olarak yüzeysel veya orta derece olarak tanıladığı dikkat çekmektedir. MT-ders öncesinde kendi matematik tarihi bilgisinin derin

|Kastamonu Eğitim Dergisi, 27(6), 2019| 
olduğunu iddia eden sadece 4 kişi (\%12) olmuştur. MT-ders sonrası yorumlar incelendiğinde ise öğretmen adaylarının kendi bilgilerine yönelik algılarında bazı önemli değişimlerin olduğu görülmektedir. Tablo 6'ya göre en belirgin değişim, MTders öncesi kendi bilgisini yüzeysel olarak tanımlayan öğretmen adaylarının sayısının MT-sonrası sıfira düştüğüdür. Diğer önemli bir değişim ise, öğretmen adaylarının büyük bir çoğunluğunun (\%90) MT-dersi sonrasında kendi matematik bilgisini orta derece olarak algılaması olmuştur. Her ne kadar MT-ders öncesi ve sonrasında kendi bilgisini derin olarak algılayan öğretmen adayı sayısı değişmemiş gibi görünse de Tablo 6 bu değişimlerin doğasını net olarak gösterememektedir. Bu nedenle, öğretmen adaylarııı MT-ders öncesi ve sonrasında kendi matematik tarihi bilgileriyle ilgili algılarındaki değişimlerin doğasını daha iyi yansıtabilmek için MT-ders öncesi ve sonrası yazılı cevaplar her bir öğretmen adayı için karşılaştırmalı analiz yaparak elde edilmiştir. Bu sayede, Tablo 7'de öğretmen adaylarının algılarında meydana gelen değişimler gruplanarak sunulmuştur. Bu değişimlerin özellikleri ve içerikleri doğrudan alıntlara yer verilerek alt başlıklar altında açıklanmıştır.

Tablo 7. Öğretmen adaylarının kendi MT bilgileriyle ilgili algılarındaki değişimler

\begin{tabular}{llll}
\hline Algısal değişimler & & Kişi sayısı \\
\hline & MT-ders öncesi & MT-ders sonrası & 16 \\
Değişim 1 & Yüzeysel & Orta derece & 9 \\
Değişim 2 & Orta derece & Orta derece & 3 \\
Değişim 3 & Orta derece & Derin & 4 \\
Değişim 4 & Derin & Orta derece & 4 \\
\hline
\end{tabular}

\section{Algısal Değişim 1: Matematik tarihini yüzeysel biliyordum, artık orta derecede bildiğimi düşünüyorum.}

Tablo 7'de görüldüğü üzere 16 öğretmen adayı MT-ders öncesinde kendi matematik tarihi bilgisini yüzeysel tanımlarken ders sonrasında kendi bilgileriyle ilgili algılarının değiştiğini belirtmiştir. Bu öğretmen adayları ders sürecinde edindikleri matematik tarihi bilgisi ve pedagojik deneyimler sonunda orta derecede bir matematik tarihi bilgisi edindiklerini MT-ders sonrası yazılı cevaplarında belirtmişlerdir. MT-ders öncesinde, kendi matematik tarihi bilgisini yüzeysel olarak tanımlayan öğretmen adayları, matematik tarihi adına sadece belli matematikçilerin adını bildiklerini (ör. Öklid, Harezmi, Pisagor) ve çok ünlü formüllerin/teoremlerin bazılarını (ör. Tales, Pisagor teoremi) geçmiş öğrenmelerinden kaynaklı bildiklerini ifade etmişlerdir. Bu kategoriye giren bir öğretmen adayının ders öncesi ve sonrasında yazdığı açıklamalar aşağıda sunulmuştur:

"Benim matematik tarihi bilgim bence oldukça sınırlı. Çünkü matematik tarihi ile ilgili ufak anekdotlar dışında pek bir şey bilmiyorum. Onları da zaten ortaokul ve lise kitaplarının içinde verilen resimlerden vs. hatırlıyorum. Öğrenme hayatım boyunca pek matematik tarihi ögrenme firsatım olmadı" [MT-ders öncesi düşünceler, ÖA1].

"Matematik tarihi hakkında çokşey öğrendim. Matematikçilerin hayatlarını ve keşiflerini öğrendim. Ayrıca, çeşitli medeniyetlerde farklı matematiksel gelişmelerin neler olduğunu fark ettim. Örneğin, eski zamanlardan modern matematik zamanlarına kadar değişken kavramının gelişimi beni çok şaşırttı. Matematik tarihi hakkında birçok şey öğrensem de, derin bilgi seviyesine sahip olduğumu söyleyemem çünkü matematik tarihi çok karmaşık konular içeriyor. Çoğu da ortaokul seviyesinde bahsetmek için uygun olmuyor" [MT-ders sonrası düşünceler, ÖA1].

Bu açıklamalar öğretmen adayının MT-ders sonrasında kendi bilgilerine dair algısında bir iyileşme olduğunu belirttiğini göstermektedir. Ayrıca MT-ders sonrası açıklamalarda kendi bilgisinin derin olmadığını belirten öğretmen adayı aslında matematik tarihi içeriğinin oldukça geniş ve derin olduğunu fark ettiğini işaret etmektedir. Başka bir deyişle, Algısal değişim-1 içinde kodlanmış öğretmen adaylarının cevapları, matematik tarihinin karmaşıklığı ve ortaokul düzeyinde uygun biçimlerde kullanımının düşündüklerinden daha zor olması nedenleriyle matematik tarihini derinden ziyade orta derecede bildiklerini belirtmiştir.

\section{Algısal Değişim 2: Matematik tarihini orta derecede biliyordum ama ders sonrasında yine orta derecede bildiğimi düşünüyorum.}

Öğretmen adaylarının 9'u hem MT-ders öncesinde hem de sonrasında sahip oldukları matematik tarihi bilgisini orta derece olarak kodlamıştır. Fakat bu öğretmen adaylarını tümü ders sonrasında matematik tarihi bilgilerinde ciddi bir artş̧ olduğunu yazılı olarak ifade etmişlerdir. Bu bilgi artışına rağmen yine de kendi bilgi seviyelerinin orta derece olduğunu belirtmişlerdir. Ek olarak, birçoğu kendisini MT-ders öncesi sahip oldukları matematik tarihi bilgisi ile algıları açısından eleştirmiştir. Belirtilen durumları örneklemek için bir öğretmen adayının MT-ders öncesi ve sonrası yaptığı yorumlar şu şekilde olmuştur: 
"Matematik tarihi hakkında bilgim fena değil. Sayıların tarihsel gelişimini biliyorum. Farklı uygarlıklarda kullanılan sayı sistemlerini biliyorum (örneğin, Mısır, Babiller). Ayrıca matematikçilerin sıfirı nasıl bulduğu hakkında bir şeyler okudum. Bunları genel olarak Bilim Tarihi dersinde ya da önceki dönemlerde matematikle ilgili diğer derslerde ögrendim" [MT-ders öncesi düşünceler, ÖA10].

"Aslında dersten önce matematik tarihi ile ilgili birçok şeyi bildiğime inanıyordum. Ancak, bilgimin saylların tarihsel gelişimi ile sinırlı olduğunu anladım. Tarihte cebirsel ve geometrik gelişmeler hakkında yeni şeyler ögrendim. Ders planları hazırlarken internet ve diğer kaynakları araştırdık. Matematik tarihi üzerinde derinleştirmek uzun bir süreç gerektiriyor bence. Matematik tarihi hakkındaki bilgim gelişti, ancak halen bu gelişimi yeterli bulmuyorum" [MT-ders sonrası düşünceler, ÖA10].

Yukarıdaki açıklamalarda görüldüğü gibi, üniversitede aldığı dersler ile (ör. Bilim Tarihi) matematik tarihini orta derece bildiğini iddia eden öğretmen adayı, dersten sonra matematik tarihinin kapsamlı yapısını fark ettiğini söylemiştir. Bu öğretmen adayına benzer şekilde, diğer öğretmen adayları da özellikle matematik tarihini matematik konuları için hazırladıkları ders planlarına entegre ederken ortaokul düzeyinde sunma konusunda zorlandıklarını ifade etmişlerdir. Örneğin, Şekil 2'de bir kesiti sunulan veri işleme ile ilgili ders planını hazırlayan Grup-11 matematik tarihini amaç olarak kullandıklarını belirtmişlerdir. Grup elemanlarına ders planında matematik tarihi kullanımına nasıl karar verdikleri sorulduğunda aşağıdaki diyalog oluşmuştur:

Araştırmacı: Ders planda matematik tarihi kullanımına nasıl karar verdiniz?

Grup-11 üyesi 1: Bizim grubun ögrenme alant istatistikti. Biz konu olarak sütun grafiğini düsündük. İstatistikteki tarihsel gelişimler ortaokula pek uygun değildi. Biz de bu yüzden bilim adamlarının yaşadıkları yüzyılları verdik ve bilim adamlarının isimleri ve yaşadıklarl yüzyıllarla ilgili bir sütun grafiği çizdirmek istedik. Bu sayede en azından matematikçilerin isimlerini ve yaşadıkları yüzyllları öğrenirler diye umduk.

Araştırmacı: Thales'i neden ayrıca anlattınız?

Grup-11 üyesi 2: Thales 'in buluşlarını ögrensinler istedik. Geometri konularındaki buluşların nerden geldiğini görürler. Belki verdiğimiz diğer isimleri de araştırmak isterler diye düşündük. Bir nevi genel kültür.

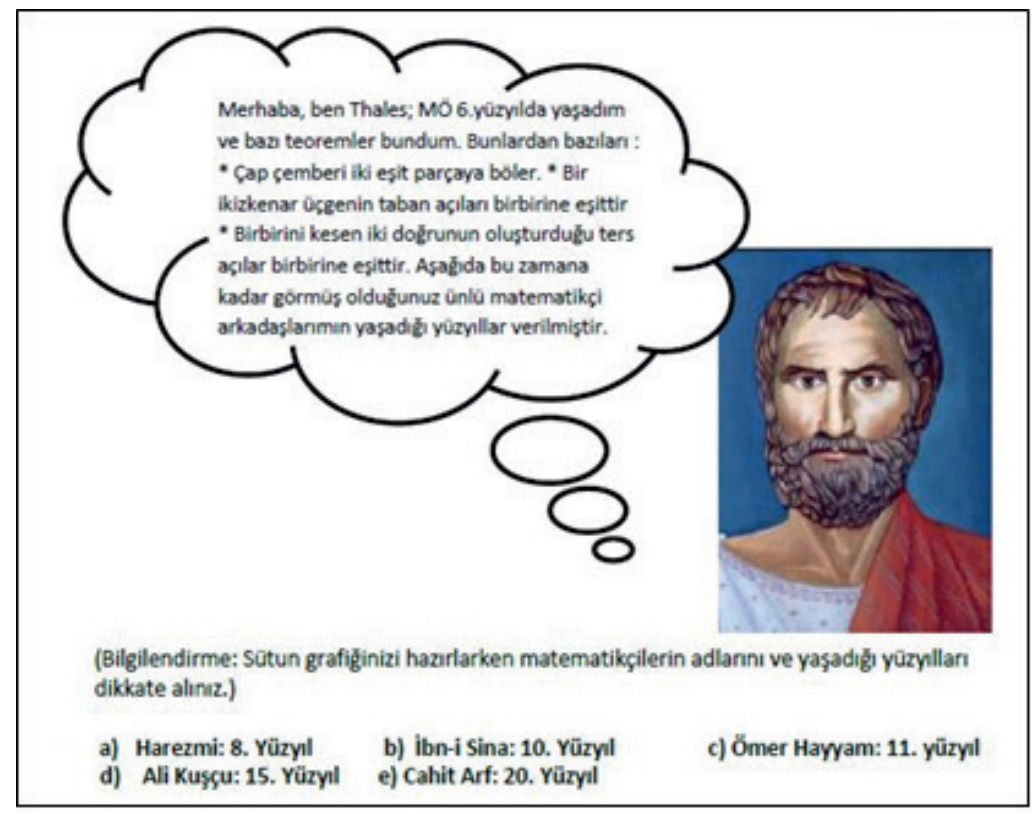

\section{Şekil 2. Grup-11'in MT içerikli ders planı kesiti}

Yukarıdaki diyalogdan görüldüğü üzere, öğretmen adayları istatistik alanındaki gelişimlerin tarihsel sürecinin diğer kavramlara göre çok daha geç olduğunu ve yapılan buluşların da genelde ortaokul matematiğini kapsamamasından dolayı matematik tarihini öğretim içeriğine yerleştirmede zorluk yaşadıklarını söylemişlerdir. Bu gibi etkenlerden ötürü de matematik tarihi bilgilerinin ders sonrasında da orta düzeyde olduğuna yönelik algılarının varlığını yazılı olarak dile getirmişlerdir. Ayrıca öğretmen adayları, sınıf tartş̧malarında seçilen öğrenme alanı ve konuda matematik tarihi içeriklerinin oldukça farklı özellikler barındırdığından ve derste kullanılacak MT içeriğinin titizlikle seçilmesi gerektiğinden bahsetmişlerdir. 


\section{Algısal Değişim 3: Matematik tarihini orta derecede biliyordum ama ders sonrasında derinlemesine bildiğimi düşünüyorum.}

Tablo 7'de üç öğretmen adayının MT-dersinden önce kendi matematik tarihi bilgileriyle ilgili algılarının orta derece olduğu görülürken MT-dersi sonrasında bu öğretmen adaylarının algıları değişmiştir. Öğretmen adayları matematik tarihi bilgilerinin ders sonrasında ciddi derecede arttğını ve bir ortaokul öğrencisine ders ortamında matematik tarihi içerikleri sunacak derecede yeterli ve derin olduğunu belirtmişlerdir. Bu değişimde ise özellikle matematik tarihi dersinde deneyimledikleri ortaokul kitaplarını inceleme ve matematik tarihi entegre edilmiş ders planı tasarlama ile tartışma yapmanın etkili olduğunu ifade etmişlerdir. Bu konuda bazı öğretmen adaylarının yorumları şöyle olmuştur:

“Çeşitli matematiksel konuların tarihsel gelişimini ögrendikten sonra ben ve grubum matematik tarihi entegre ederek bir ders planı tasarladık. Bu benim için harika bir deneyim oldu. Matematik tarihi hakkında bilgimi arttırdım ve matematik tarihini derslerimde nasıl kullanabileceğimi düşündüm. Böylece, matematik derslerinde matematik tarihi kullanımı konusundaki bilgilerimi derinleştirdim" [MT-ders öncesi düşünceler, ÖA14].

"Şu an matematiğin tarihi hakkında daha fazla şey biliyorum. Çeşitli matematik konu ve süreçlerinde matematikçilerin ve medeniyetlerin çalışmalarına aşinayım. Matematikçilerin uyguladıkları çeşitli yöntemleri nasıl ve nerede bulabileceğimi biliyorum (örneğin, Pisagor Teoreminin çoklu yollarl). Bununla ilgili bir araştırma yapmak istersem, hangi kaynakları kullanabileceğimi öğrendim" [MT-ders sonrası düşünceler, ÖA3].

Yazılı açıklamalarda görüldüğü üzere, ÖA14 matematik tarihi bilgisindeki değişimi pedagojik açıdan ele almıştır. Bunun bir sonucu olarak, matematik tarihi bilgisini yeterli ve derin olarak algılamıştır. ÖA14'ün bulunduğu grubun hazırladığı ders planı içeriği incelendiğinde matematik tarihini ders planında nasıl kullandıkları ve nasıl bu düşüncelere eriştiği hakkında daha detaylı bilgi edinilebilir. ÖA14'ün de içinde olduğu Grup-6, cebir öğrenme alanında cebir, eşitlik ve denklem konusunda bir ders planı hazırlamışlardır. Bu ders planında Ek-1'de görüldüğü üzere farklı matematikçilerin kullandıkları denklem çözümleme ve doğrulama (ör. Harezmi'nin denklemdeki negatif terimi ortadan kaldırma yöntemi, Ali Kuşçu'nun İkili Yanlışlama ve Tahlil Yöntemleri il denklem çözümü) yöntemlerine yer vermişlerdir. Grup ders planı sonuna eklediği açıklamada çocuklara farklı çözüm yöntemleri ile modern çözüm yöntemlerini göstermenin onların matematiğe olan motivasyonu olumlu etkileyeceğine dair açıklamalar da eklemiştir. Bu grup, matematik tarihini konunun öğretimi ve öğrencileri matematiğe karşı motive etme amaçlarıyla ele aldıkları için MT’yi araç olarak kullanmışlardır. ÖA14'ün MT bilgisinde derinliğe ulaştı̆̆ yönünde değişen algısı ders planlarındaki yoğun MT içeriği ve seçtikleri cebir konusunun ortaokul düzeyinde matematik tarihi entegrasyonuna uygun olmasıyla ilişkili olabilir. Bu anlamda, ÖA14'ün açıklamaları da belirtilen durumu desteklemiştir. Diğer taraftan, Pisagor Teoremi'nin kullanıldığı ders planı grubunda bulunan ÖA3 de MT-ders sonrası düşüncelerinde benzer cümleler yazmıştır. Öğretmen adaylarının yorumları, onların matematik tarihiyle ilgili kayda değer noktalar öğrendiklerini ve özellikle matematik tarihini pedagojik firsatlar yaratmada nasıl kullanacakları konusunda derinleştiklerini düşündüklerini göstermiştir. Bu nedenle, bu kategorideki algısal değişimlerde temel olarak matematik tarihi genel kültür bilgisi gelişimi yerine pedagojik açıdan yaşanan gelişimlere yönelik söylemler öne çıkmıştır.

\section{Algısal Değişim 4: Matematik tarihini derinlemesine bildiğimi düşünüyordum ama ders sonrasında orta derece bildiğimi düşünüyorum.}

İlginç bir şekilde ders öncesinde kendi matematik tarihi bilgisini derin olarak tanımlayan 4 öğretmen adayı ders sonrasında fikrini değiştirmiştir. Bu dört öğretmen adayı MT-ders öncesi yazılı cevaplarında matematik tarihine kişisel ilgi duydukları yönünde açıklamalara yer vermişlerdir. Bu ilgi doğrultusunda zaman zaman belli matematik tarihi içerikli dergiler ve kitaplar okuduklarını ve videolar izlediklerini ifade etmişlerdir. Fakat bu öğretmen adayları MT-dersi sonrasında edindikleri pedagojik deneyimlerin etkisi ile kendi matematik tarihi bilgilerini matematik tarihinin öğretimsel boyutlarını da düşünerek artık orta derece olarak algıladıklarını söylemişlerdir. Bu noktada, bir öğretmen adayının yazdığı yorumlarla belirtilen durum daha iyi açıklanmaya çalışılmıştır.

"Matematik tarihi hakkındaki bilgimin derin olduğunu düşünüyorum çünkü ben matematik tarihi ile kişisel olarak da ilgileniyorum. Örneğin, ilk önce sayıları bulma hakkında konuşabiliriz. Romalılar veya Mısırlılar olsun, birçok medeniyet, çevremizde gördüğ̈̈müz varlıkları temsil etmek için işaretlere ihtiyaç duyuyordu. Bu nedenle farklı temsiller kullandılar. Birçok bilim adamı, matematik tarihinde de büyük gelişmeler olduğunu göstermiştir. Hipotenüsün varlı̆̆l, örneğin en kısa yol olarak bir üçgenin yardımcı elemanıydı. Öte yandan, örüntülerin sanat tarihinin gelişimi üzerinde büyük etkisi oldu. Diğer bir örnek Fibonacci 
dizisinin keşfidir. Farabi, Ali Kuşçu, Ömer Hayyam, El-Harezmi, İbn-i Sina gibi matematikçilerden örnekler verebiliriz. Bütün bu icatlar, aydınlanma döneminden bu yana mühendislik ve detaylı hesaplamalarda büyük öneme sahiptir" [MT-ders öncesi düşünceler, ÖA12].

"Ben aslında matematik tarihi bilgimi yüksek buluyordum. Fakat derste ortaokul matematik konularında kullanmak için yaptığımız çalışmalarda matematik tarihini derse etkili biçimde bütünleştirmek pek kolay olmadı. Çünkü öylesine bir bilim insanının hayatını anlatmak tam manada matematik tarihini kullanmak olmuyor. Diğer bir konu da ortaokul müfredatında kullanılacak uygun tarihsel içerik bulmak zor. Yapılan çalışmalar genelde üst-düzey matematik ile ilgili oluyor. Bu ders bana matematik tarihinde ögrenilecek çok fazla şey olduğunu gösterdi o yüzden ben bilgimin orta olduğunu söyleyebilirim" [MT-ders sonrası düşünceler, ÖA12].

Sonuç olarak, matematik tarihini MT-dersi öncesinde derin bildiğine inanan öğretmen adayları derste edindikleri pedagojik deneyimler sonucunda bu konudaki algılarını değiştirmiştir. MT-dersi öncesinde kendi bilgilerine yönelik abarttı bir algıya sahip oldukları sonucuna varmışlardır. Öğretmen adaylarının yaptığı yorumlarda öğretmenlerin sadece bir genel kültür edinme çabasıyla değil aynı zamanda öğretimi güçlendirme ve öğrenciyi duyuşsal anlamda destekleme amacı güderek matematik tarihini öğrenmeye çalıştkları gözlemlenmiştir. Bu nedenle de, MT-ders sonrasında daha çok öğretim ve öğrenci boyutunda matematik tarihi bilgilerini değerlendirerek bu bilgilerin derin diye isimlendirebilecekleri düzeyde olmadığını vurgulamışlardır.

\section{Sonuç ve Tartışma}

Bu araştırma, ilköğretim matematik öğretmeni adaylarının Pedagojik Deneyimler içeren Matematik Tarihi dersi öncesinde ve sonrasında matematik tarihi bilmenin gerekliliğiyle ve kendi matematik tarihi bilgileriyle ilgili algılarının neler olduğunu ve bu algılarda nasıl değişimler yaşandığını keşfetmeyi amaçlamıştır. Araştırma sonuçları, öğretmen adaylarının matematik öğretmenlerinin (i) genel kültür ve saygınlık kazanmak, (ii) konu alan bilgilerini güçlendirmek, (iii) öğretim sürecini güçlendirmek ve (iv) öğrencileri matematiğe karşı duyuşsal olarak desteklemek için matematik tarihi bilmeleri gerektiği düşüncelerine sahip olduklarını göstermiştir. MT-ders öncesinde öğretmen adaylarının öğretmenlerin matematik tarihini en çok öğretim sürecini güçlendirmek için bilmeleri gerektiğini düşündükleri görülürken, MT-ders sonrasında bu düşünce daha çok öğrencileri matematiğe karşı duyuşsal olarak destekleme fikrine yoğunlaşmıştr. Örneğin, özellikle veri işleme öğrenme alanında ders planı hazırlayan grup istatistik için matematik tarihi içeriği bulmanın zor olduğunu ve özellikle de bunu ortaokul konularına aktarmanın zorluklarından bahsetmişlerdir. Öğretmen adaylarının değişen düşünceleri ortaokul düzeyinde matematik tarihi bilgisini derslere entegre etmenin belli zorlukları olduğunu fark etmeleriyle ilişkili bulunmuştur. Bir diğer etken ise inceledikleri ders kitap içeriyle ilgili olabilir. Çünkü ilköğretim ders kitaplarında sunulan matematik tarihi içerikleri matematik tarihini Jankvist 'in (2009) aydınlatma yaklaşımı çerçevesinde sadece bir motivasyonel araç olarak ele almaktadır (Baki ve Bütüner, 2013). Bu noktada, öğretmen adaylarının gerek yazııı açıklamaları gerek ders içinde yapılan tartşmalardaki söylemleri, ders kitaplarında verilen matematik tarihi içeriklerini ve matematik tarihi entegre edilmiş ders planlarını/çalışma kağıtlarını inceledikçe matematiksel ve tarihsel içeriklerin öğretimi güçlendirmeye ek olarak derslerde öğrencileri matematiğe karşı güdülemede de etkin biçimde kullanılabileceği fikrini benimsemeye başladıklarını göstermiştir. Diğer taraftan, MT-ders sonrasında elde edilen sonuçlar öğretmen adaylarının matematik tarihini öğretmenlerin genel kültür edinme ve saygınlık kazanma amacıyla öğrenmesi gerektiği fikrinde belirgin bir azalmanın olduğunu göstermiştir. Asında bu durum öğretmen adaylarının matematik tarihini bir amaç olarak öğrenme ve kullanma fikrinden bir miktar uzaklaştklarını göstermiştir (Jankvist, 2009).

Araştırma sonuçları, öğretmen adaylarının kendi matematik tarihi bilgileriyle ilgili algılarında da pedagojik deneyimler içerin MT-ders öncesi ve sonrası kıyaslandığında önemli değişimler olduğunu ortaya çıkarmıştır. Matematik tarihi bilgileriyle ilgili algılardaki genel değişimler görsel olarak Şekil 3'te sunulmuştur. MT-ders öncesinde matematik tarihi bilgisini sadece belli formül ve bilim insanların isimlerini bilmeleri nedeniyle yüzeysel olarak tanımlayan öğretmen adaylarının tamamının MT-ders sonrasında bilgilerini orta düzeye atadıkları tespit edilmiştir. Fakat benzer bir durum MT-ders öncesinde kendilerinin orta derece ve derin anlamda matematik tarihi bildiğini belirten öğretmen adaylarında gözlenmemiştir. Örneğin, MT-ders öncesinde sahip oldukları matematik tarihi bilgisini derin olarak tanımlayan öğretmen adaylarının tümü ders sonrasında sahip oldukları bilgiyi orta derece olarak atayabileceklerini belirtmişlerdir. Benzer şekilde, MT-öncesi sahip olduğu matematik tarihi bilgisinin orta derece olduğu algısına sahip olan öğretmen adaylarının çoğu ders sonrasında bu algılarına yönelik özeleştiri yaparak aslında MT-dersi sonrasında orta derece bir bilgi düzeyine erişebildiklerini belirtmişlerdir. Bu durum öğretmen adaylarının bilgi ve tecrübelerinin artmasıyla kendilerini kritik etme ve kendi bilgi düzeylerine daha gerçekçi bir gözle bakmaya çalıştklarına işaret etmektedir. Bu bakış açısını geliştirirken de derste edindikleri pedagojik tecrübelerin ve matematik tarihi içeriklerinin önemli bir etken olduğunu

| Kastamonu Eğitim Dergisi, 27(6), 2019| 
ortaya koymuşlardır. Bu durum, kendine güven ve sahip olunan tecrübe arasındaki ilişkiyi inceleyen popüler bir çalışma sonucuyla büyük benzerlikler taşımaktadır (Kruger ve Dunning, 1999). Kruger-Dunning (1999) bir konuda yetkin olmayan insanların o konudaki bilgi ve becerilerini abarttı̆̆ın ve bu kişilerin o konuda eğitim aldığı takdirde eksikliklerini fark ederek onları kabul ettiklerini ortaya çıkarmıştır.

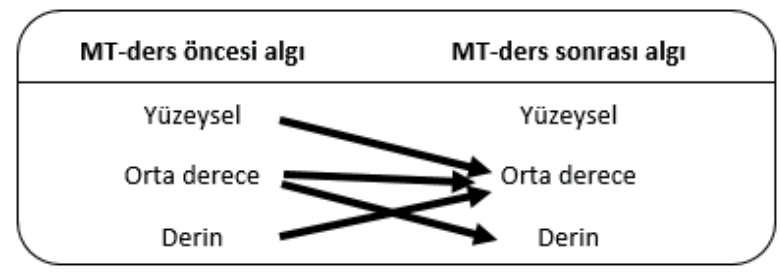

\section{Şekil 3. Öğretmen adaylarının kendi MT-bilgileriyle ilgili ortaya çıkan algısal değişimler}

Bu araştırmada edinilen sonuçların birçok anlamda alana katkı sağlayacağı düşünülmektedir. Alan yazında bazı çaıışmalar öğretmenlerin matematik tarihini derslerinde kullanmanın yararlı olmadığına inandıklarını dile getirmektedir (Lit, Siu ve Wong, 2001; Siu, 2007). Bu durum için öğretmenlerin matematik tarihi ile ilgili bilgi ve tecrübe eksikliğinin olması (Barbin, Bagni, Grugnetti, Kronfeller, Lakoma ve Menghini, 2000; Gazit, 2013; Lit ve Wong, 1999; Panasuk ve Horton, 2012; Siu, 2007) ve özgüvenlerinin düşük olması (Panasuk ve Horton, 2012; Siu, 2007; Yıldız ve Baki, 2016) gerekçe olarak gösterilmektedir. Yapılan bu araştırma, öğretmen adaylarına matematik tarihinin derslerde nasıl ve ne biçimlerde kullanabileceğini pedagojik deneyimler ile birlikte sunduğu için öğretmen adaylarının bilgi ve tecrübelerini desteklemiştir. Bu sayede, onların matematik tarihi ve kullanımını bir önyargı ile değil sahip oldukları tecrübe ışığında ele almaya çalışmalarına yardımcı olmuştur. Bu konuda kazanılan farkındalık, öğretmen olduklarında matematik tarihi ve kullanımı ile ilgili yaşayacakları sıkıntıların önüne geçmede faydalı olabilir. Çünkü öğretmenler lisans programı kapsamında matematik tarihini genelde sadece bir genel kültür dersi olarak pedagojik deneyimlerden yoksun tecrübe ettikleri için hangi matematik konusunda hangi tarihsel bilgiyi nasıl entegre edecekleri öğretmenlerin karşısına bir sorun olarak çıkmaktadır. Örneğin, Baki ve Yıldız (2010) öğretmenlerin matematik tarihiyle ilgili kısımları derslerinde nasıl kullanabilecekleri hakkında net bir fikir sahibi olmadıklarını belirtmektedir. Alan yazında öğretmenler için her ne kadar matematik tarihi içeriği zengin kitaplar hazırlanması ve ilköğretim öğretim programlarının matematik tarihini kullanmayı zorunlu kılması önerilse de (Yıldız ve Baki, 2016) öğretmenlerin matematik tarihi ile ilgili derin bilgiler edinebilecekleri en önemli yer lisans eğitim sürecidir. Bu araştırmanın sonuçları, öğretmen adaylarının matematik tarihi ile ilgili gerçekçi bir bakış kazanarak kendi bilgilerini kritik ettiklerini göstermiştir. Bu yönüyle yapılan bu araştırma, matematik tarihi içeriklerinin ve bu içeriklerin öğretim süreçlerine entegrasyonunun yetkin uzmanların rehberliği vasıtasıyla kazanılabileceği görüşünü desteklemiştir (Leng, 2006).

Son olarak, çalışma sonuçları üzerine inşa edilmiş ve gelecek araştırmalara yön verecek önerilere yer verilmiştir. Daha önce de bahsedildiği gibi yapılan çalışmalar, matematik tarihinin ortaokul matematik derslerine olan entegrasyonuna yönelik önerilere yoğunlukla yer vermektedir. Bu araştırma lisans programında son sınıfta öğrenim gören öğretmen adaylarına matematik tarihini ortaokul düzeyinde ders planlarına entegre etme firsatı sunmuştur. Fakat yeni lisans programında Matematik Tarihi dersi dördüncü sınıftan birinci sınıfa alındığı için lisans programının ilk yılında olan öğretmen adaylarına matematik tarihi ile ilgili tanınacak pedagojik içerikler farklııklar gösterebilir. Çünkü öğretmenlik lisans programlarının ilk yılında ders planı hazırlama ve kitap analizi gibi pedagojik içerikli derslere genelde yer verilmediği için lisans programının birinci sınıfindaki öğretmen adaylarının matematik tarihi entegre edebilecek bilgi birikimine erişmeleri zor görünmektedir. Bu nedenle, ileriki çalışmalarda yeni programa göre Matematik Tarihi dersi alan öğretmen adaylarıyla yapılacak çalışmaların sonuçları, bu araştırmanın sonuçlarıyla birlikte yorumlanarak yeni programın etkililiğinin ve uygunluğunun teyit edilmesine katkı sağlayabilir. Diğer taraftan, bu araştırmada ders planları, öğretmen adaylarına matematik tarihi ile ilgili pedagojik firsatlar sunmak için istenmiştir. Fakat ileriki çalışmalarda öğretmen adaylarının ders öncesi ve sonrasında neleri nasıl planladıklarına, matematik tarihini hangi amaçla ele aldıklarına bakılabilir. Daha da ötesi, öğretmen adayları MT-içerikli ders planlarını okul deneyimi ve öğretmenlik uygulaması derslerinde hayata geçirerek ders imecesi kapsamında revize edebilirler. Böylece öğretmen adayları, MT-içerikli bir dersin öğrencileri bilişsel ve duyuşsal bakımdan nasıl etkilediğini gözlemleyerek ders planlarını matematiksel ve pedagojik açıdan daha uygun içeriklerle zenginleştirebilirler. Ayrıca bu çalışma öğretmen adaylarının öğrenme alanları ve matematik tarihi entegrasyonu arasında belli ilişkiler kurduğuna işaret etmiştir. Örneğin, öğretmen adayları veri işleme öğrenme alanında MT-içerikleri oluşturmayı zor bulurken, sayılar konusunda daha keyifli ve kolay plan hazırladıklarını dile getirmişlerdir. Bu nedenle yapılacak çalışmalarda, öğrenme alanı ve öğretmen adaylarının matematik tarihi entegre etme ve konuyu ele alış biçimleri arasındaki ilişkiler incelenebilir. 


\section{Kaynakça}

Albayrak, Ö. (2011). Matematik tarihiyle işlenmiş olan derslerin matematik öz yeterlik algısına ve matematik başarısına etkisi. Yayınlanmamış yüksek lisans tezi, Boğaziçi Üniversitesi, İstanbul.

Alpaslan, M. (2011). Prospective elementary mathematics teachers' knowledge of history of mathematics and their attitudes and beliefs towards the use of history of mathematics in mathematics education. Yayınlanmamış yüksek lisans tezi, ODTÜ, Ankara.

Alpaslan, M., \& Haser, Ç. (2012). History of mathematics course for pre-service mathematics teachers: A case study. In 12th international congress on mathematical education pre-proceedings (ss. 4180-4189). Seoul, South Korea.

Bagni, G. T. (2008). A theorem and its different proofs: History, mathematics education and the semioticcultural perspective. Canadian Journal of Science, Mathematics, and Technology Education, 8(3), 217-232.

Baki, A. (2014). Matematik Tarihi ve Felsefesi. Ankara: Pegem Akademi Yayıncılık.

Baki, A., \& Bütüner, S. Ö. (2013). 6-7 ve 8. sınıf matematik ders kitaplarında matematik tarihinin kullanım şekilleri. ilköğretim Online, 12(3), 849-872.

Baki, A., \& Güven, B. (2009). Khayyam with cabri: Experiences of pre-service mathematics teachers with Khayyam's solution of cubic equations in dynamic geometry environment. Teaching Mathematics and Its Applications, 28, 1-9.

Baki, A., \& Yıldız, C. (2010). Matematik tarihi etkinlikleriyle zenginleştirilmiş sınıf ortamından yansımalar. II. Uluslararası Türkiye Eğitim Araştırmaları Kongre Kitabı (ss. 563-577). Antalya: Eğitim Araştırmaları Birliği.

Barbin, E., Bagni, G. T., Grugnetti, L., Kronfellner, M., Lakoma, E., \& Menghini, M. (2000). Integrating history: Research perspectives. In J. Fauvel \& J. Van Maanen (Eds.), History in Mathematics (ss. 63-90). Springer, Dordrecht.

Barwell, M. E. (1913). The advisability of including some instruction in the school course on the history of mathematics. The Mathematical Gazette, 7(104), 72-79.

Başıbüyük, K. (2012). Matematik tarihinin matematik derslerinin öğretiminde kullanılması: Ibrahim Hakkı perspektifi ve Babil yöntemi örneği, Yüksek Lisans Tezi, Atatürk Üniversitesi, Eğitim Bilimleri Enstitüsü: Erzurum.

Bayam, S. B. (2012). Illköğretim matematik eğitiminde öğrencilerin matematik tarihini bilmelerinin matematiğe yönelik başarı ve tutumlarına etkisi. Yayınlanmamış yüksek lisans tezi, Kastamonu Üniversitesi, Kastamonu.

Bütüner, S. Ö. (2011). Örüntü ve ilişkiler: Eski Çin matematiğinden alınmış birim küp modelleri. illköğretim Online, 10(3), 1-8.

Carter, D. B. (2006). The role of the history of mathematics in middle school. Unpublished master's thesis, East Tennessee State University, United States.

Clark, K. (2012). History of mathematics: Illuminating understanding of school mathematics concepts for prospective mathematics teachers. Educational Studies in Mathematics, 81(1), 67-84.

Ellington, R. (1998). The importance of incorporating the history of mathematics into the Standards 2000 draft and the overall mathematics curriculum. EDCI 650 Reacts: History of Mathematics. University of Maryland.

Erdoğan, A., Eşmen, E., \& Fındık, S. (2015). Ortaokul matematik ders kitaplarında matematik tarihinin yeri: Ekolojik bir analiz. Marmara Üniversitesi Atatürk Eğitim Fakültesi Eğitim Bilimleri Dergisi, 42, 239-259.

Ersoy, E., \& Öksüz, C. (2016). İlkokul 4. sınıflarda matematik tarihi kullanımının öğrenciler üzerindeki etkileri. illköğretim Online, 15(2). 408-420.

Fauvel, J. (1991). Using history in mathematics education. For the Learning of Mathematics, 11(2), 3-6.

Freudenthal, H. (1981). Should a mathematics teacher know something about the history of mathematics? For the Learning of Mathematics, 2(1), 30-33.

Fried, M. (2001). Can mathematics education and history of mathematics coexist? Science and Education, 10(4), 391-408.

Furinghetti, F. (2004). History and mathematics education: A look around the world with particular reference to Italy. Mediterranean Journal for Research in Mathematics Education, 3(1-2), 1-19.

Furinghetti, F. (1997). History of mathematics, mathematics education, school practice: Case studies linking different domains. For the Learning of Mathematics, 17(1), 55-61.

Furinghetti, F., \& Karp, A. (2018). Researching the History of Mathematics Education. Cham: Springer International Publishing, https://doi.org/10.1007/978-3-319-68294-5.

Furinghetti, F., \& Radford, L. (2002). Historical conceptual developments and the teaching of mathematics: From phylogenesis and ontogenesis theory to classroom practice. In D. L. English (Ed.), Handbook Of International Research in Mathematics Education (ss. 631-654). Mahwah, NJ: Lawrence Erlbaum.

Gazit, A. (2013). What do mathematics teachers and teacher trainees know about the history of mathematics? International Journal of Mathematical Education in Science and Technology, 44(4), 501-512.

Genç, M., \& Karataş, İ. (2018). Matematik tarihinin matematik öğretimine entegrasyonu: Hârezmî'nin tam kareye tamamlama yöntemi, Kastamonu Eğitim Dergisi, 26(1), 1-12.

Gönülateş, F. (2008). Prospective teachers' views on the integration of history of mathematics in mathematics courses. Paper presented at HPM 2008 satellite meeting of ICME-11. 
Gürsoy, K. (2010). ilköğretim matematik öğretmen adaylarının matematik tarihinin matematik öğretiminde kullanılmasına ilişkin inanç ve tutumlarının incelenmesi. Yayınlanmamış Yüksek Lisans Tezi, Karadeniz Teknik Üniversitesi, Trabzon.

Hatisaru, V., Erbaş, A. K., \& Çetinkaya, B. (2011). Using history of mathematics in teaching mathematics: Teachers' views. In B. Ubuz (Ed.), Proceedings of the 35th Conference on the International Group for the Psychology of Mathematics Education (Vol. 1, p. 312), Ankara, Turkey: PME.

Jankvist, T. U. (2009). A categorization of the whys and hows of using history in mathematics education. Educational Studies in Mathematics Education, 71(3), 235-261.

Karakuş, F. (2009). Matematik tarihinin matematik öğretiminde kullanılması: Karekök hesaplamada babil metodu. Necatibey Eğitim Fakültesi Elektronik Fen ve Matematik Eğitimi Dergisi (EFMED), 3(1), 195-206.

Kaşıkçı, M. (2015). Matematik tarihi dersinde drama yönteminin ilköğretim matematik öğretmen adaylarının bilgi, inanç ve tutumlarına etkisi, Dokuz Eylül Üniversitesi Eğitim Bilimleri Enstitüsü. Yayınlanmamış Yüksek Lisans Tezi, Dokuz Eylul University, İzmir.

Kruger, J., \& Dunning, D. (1999). Unskilled and unaware of it: How difficulties in recognizing one's own incompetence lead to inflated self-assessments. Journal of Personality and Social Psychology, 77(6), 1121-1134.

Leng, N. W. (2006). Effects of an ancient Chinese mathematics enrichment programme on secondary school students' achievement in mathematics. International Journal of Science and Mathematics Education, 4(2), 485-511.

Lit, C. K., Siu, M., \& Wong, N. (2001). The use of history in the teaching of mathematics: Theory, practice, and evaluation of effectiveness. Education Journal, 29(1), 17-31.

Lit, C. K., \& Wong, N. Y. (1999). A study on the use of history of mathematics in mathematical instruction among Hong Kong secondary school teachers. Curriculum Forum, 8, 50-65.

Mersin, N., \& Durmuş, S. (2018). Matematik tarihinin ortaokul matematik ders kitaplarındaki yeri. Abant Izzet Baysal Üniversitesi Eğitim Fakültesi Dergisi. 18(2), 997-1019.

Özdemir, A. Ş., \& Yıldız, S. G. (2015). Sınıfta matematik tarihinin kullanımına bir örnek: Babil sayma sistemi. Amasya Üniversitesi Eğitim Fakültesi Dergisi, 4(1), 26-49.

Panasuk, R. M., \& Horton, L. B. (2012). Integrating history of mathematics into curriculum: What are the chances and constraints? International Electronic Journal of Mathematics Education, 7(1), 3-20.

Philippou, G. N., \& Christou, C. (1998). The effects of a preparatory mathematics program in changing prospective teachers' attitudes towards mathematics. Educational Studies in Mathematics, 35(2), 189-206.

Radford, L. (2000). Signs and meanings in students' emergent algebraic thinking: A semiotic analysis. Educational Studies in Mathematics, 42(3), 237-268.

Savizi, B. (2007). Applicable problems in the history of mathematics: Practical examples for the classroom. Teaching Mathematics and Its Applications, 26(1), 45-50.

Siu, M. K. (2007). No, I don't use history of mathematics in my class. Why? In F. Furinghetti, S. Kaijser, \& C. Tzanakis (Eds.), Proceedings of the History and Pedagogy of Mathematics 2004 \& European Summer University 4 (ss. 268-277). Uppsala: Uppsala University.

Sözen, S. (2013). Sınıf ve matematik öğretmenlerine göre matematik tarihinin matematik öğretimine katılması üzerine bir olgubilim çalışması, Yayımlanmamış Yüksek Lisans Tezi, Orta Doğu Teknik Üniversitesi, Sosyal Bilimler Enstitüsü: Ankara.

Tan-Şişman, G., \& Kirez, B. (2018). History of mathematics in the Turkish middle school mathematics curriculum and textbooks. Çukurova University. Faculty of Education Journal, 47(1), 188-215.

Tözlüyurt, E. (2008). Sayılar öğrenme alanı ile ilgili matematik tarihinden seçilen etkinliklerle yapılan dersler hakkında lise son sınıf öğrencilerinin görüşleri, Yüksek Lisans Tezi, Gazi Üniversitesi, Eğitim Bilimleri Enstitüsü: Ankara.

Tzanakis, C., \& Arcavi, A. (2000). Integrating history of mathematics in the classroom: An analytic survey. In J. Fauvel \& J. van Maanen (Eds.), History in Mathematics Education-The ICMI Study (ss. 201-240). Dordrecht: Kluwer Academic.

Yenilmez, K. (2011). Matematik öğretmeni adaylarının matematik tarihi dersine ilişkin düşünceleri. Pamukkale Üniversitesi Eğitim Fakültesi Dergisi, 30(30), 79-90.

Yıldız, C., \& Baki, A. (2016). Matematik tarihinin derslerde kullanımını etkileyen faktörlere ilişkin öğretmen görüşleri. Ahi Evran Üniversitesi Kırşehir Eğitim Fakültesi Dergisi, 17(2), 451-472.

Yüksek Öğretim Kurumu [YÖK]. (2018). ilköğretim Matematik Öğretmenliği Lisans programları ders içerikleri kaynak dokumanı, Ankara: YÖK.

Yüksek Öğretim Kurumu [YÖK]. (2007).ilköğretim Matematik Öğretmenliği Lisans programları ders içerikleri kaynak dokumanı, Ankara: YÖK.

Weng Kin, H. (2008). Using history of mathematics in the teaching and learning of mathematics in Singapore. In Proceedings of 1st RICE (ss.1-38), Singapore. 
EK-1: Grup-6’nın Matematik Tarihi İçerikli Ders Planından Kesitler

\section{Grup-6 Matematik tarihi içerikli ders planı (biçimsel olarak düzenlenmiş kesiti-1)}

Öğrenme alani: Cebir

Konu: Cebir, Eșitlik ve Denklem

Kazanım: Birinci dereceden bir bilinmeyenli denklemleri çōzer.

\section{Açıklama:}

Harezmî bir denklemde negatif terimlerin ortadan kaldırılması işlemini ifade etmektedir. $3 x+2=4-$ $2 x$ eşitliğinin $5 x=2$ olarak yazılması "al-jabr" ifadesine karşılık gelmektedir. Eşitliğin her iki tarafına $2 x$ eklenerek negatif terimlerin yok edilmesi eşitligin çözümünü kolaylaştırmaktadır. "Al-muqabala" terimi ise dengeleme anlamına gelmektedir ve denklemin iki tarafında aynı kuvvetten pozitif terimlerin indirgenebileceğini ifade etmektedir. $5 x+2=4$ eșitliğinin $5 x=2$ olarak yazılması "al-muqabala" ifadesine karşııık gelmektedir. Aslında Harezmînnin yaptığı bu işlem günümüz cebir anlayışını yansıtmaktadır. Harezmînnin bu çalıșmasından yola çıkarak bizde sorularımızı çözmeye çalışalım." der.

Soru:

$5 x+3=12-2 x$ işlemini Harezmi'nin "al-jabr, al-muqabala" çalışmasına göre çözümleyiniz.

Çözüm:

1. Adım: Negatif terimi ortadan kaldırmak için her iki tarafa da $2 x$ ifadesini ekleriz. (al-jabr)

$$
5 x+2 x+3=12+2 x-2 x
$$

$$
7 x+3=12
$$

2. Adım: Aynı kuvvetten pozitif terimlerin de indirgeneceğini ifade eder. Her iki taraftan da 3 'ü çıkarırız. (al-muqabala)

$$
7 x+3-3=12-3
$$

\section{Grup-6 Matematik tarihi içerikli ders planı (biçimsel olarak düzenlenmiş kesiti-2)}

Denklem çözümünde farklı bakış açısı kazanmaları amacıyla Ali Kuşçu'nun “ikili Yanlışlama ve Tahlil Yöntemlerine" yer verilir. Öncelikle bir problem üzerinden önce ikili yanlığlama yöntemiyle çözüm yaptırılır. Daha sonra günümüz yöntemiyle çözüm yaptırılır.

\section{Problem:}

Bir sayının iki katını alalım. Buna bir ekleyelim. Bu toplamı üç ile çarpalım. Sonuca iki ekleyelim ve 4 ile çarpalım. Çıkan sonuca üç eklersek sonuç 95 çıkar. Ilk başta seçtiğimiz sayı kaçtır?

Çözüm:

ilk tahminde aranan sayı 2 olsun.

Sonuç 71 olur.

Hata $95-71=24$ olur.

Buna 1. Hata diyelim.

İkinci tahminde aranan sayı 5 olsun.

Sonuç 143 olur.

Hata $95-143=-48$ olur.

Öĕretmen bugünkü gösterimle sorunun cebirsel ifadesini sorar. Öĕrencilerin $4[3(2 x+1)+2]+3=95$ ifadesine ulaşmaları beklenir. Ali Kuş̧̧u'nun tahlil yöntemine burada yer verir.

\begin{tabular}{l|lc} 
Çözüm: & 1. Adım: & $95-3=92$ \\
Tahlil yönteminde & 2. Adım: & $92 / 4=23$ \\
\multicolumn{1}{|l|}{ 4. [3. $(2 x+1)+2]+3=95$} & 3. Adım: & $23-2=21$ \\
ifadesinde sondan başa doğru işlemlerin tersi uygulanır. & 4. Adım: & $21 / 3=7$ \\
Yani çarpma işlemi ise bölme gibi denir ve çözüm uygulatılır. & 5. Adım: & $7-1=6$ \\
& 6. Adım: & $6 / 2=3$
\end{tabular}

Hataların işaretleri farklı olduğu için 1.tahmin ile 2. Hata, 2.tahmin ile 1.hata çarpılır. Sonuçlar toplanır. Bu toplam birinci hata ile ikinci hatanın toplamına bölünerek aranan sayı bulunur.
İşlemler yapıldığında: $43.2=96$

$24.5=120$

Hataların toplamı:

$120+96=216$

Aranan sayı:

$216 / 72=3$ 